\author{
UNIVERSIDADE DE SÃO PAULO \\ FACULDADE DE ODONTOLOGIA DE BAURU
}

Mônica Garcia Ribeiro

Avaliação de nova técnica não cirúrgica para tratamento de deficiência de papila em área estética: estudo clínico randomizado controlado 

Mônica Garcia Ribeiro

\section{Avaliação de nova técnica não cirúrgica para tratamento de deficiência de papila em área estética: estudo clínico randomizado controlado}

Tese apresentada a Faculdade de Odontologia de Bauru da Universidade de São Paulo para obtenção do título de Doutor em Ciências no Programa de Ciências Odontológicas Aplicadas, na área de concentração Reabilitação Oral.

Orientador: Profa. Dra Adriana Campos Passanezi Sant'Ana

\section{Versão Corrigida}




\begin{tabular}{|l} 
Ribeiro, Mônica Garcia \\
Avaliação de nova técnica não cirúrgica para \\
tratamento de deficiência de papila em área estética: \\
estudo clínico randomizado controlado/ Mônica Garcia \\
Ribeiro. - Bauru, 2015. \\
92 p. : il. ; $31 \mathrm{~cm}$. \\
Tese (Doutorado) - Faculdade de Odontologia de \\
Bauru. Universidade de São Paulo \\
Orientador: Profa. Dra. Adriana Campos Passanezi \\
Sant'Ana
\end{tabular}

Nota: A versão original desta tese encontra-se disponível no Serviço de Biblioteca e Documentação da Faculdade de Odontologia de Bauru - FOB/USP.

Autorizo, exclusivamente para fins acadêmicos e científicos, a reprodução total ou parcial desta dissertação/tese, por processos fotocopiadores e outros meios eletrônicos.

Assinatura:

Data:

Comitê de Ética da FOB-USP

Protocolo $n^{\circ}$ : 019356/2013

Data: $24 / 04 / 2013$ 


\section{FICHA TÉCNICA}

Mônica Garcia Ribeiro:

triagem, operador, redação

Adriana C P Sant'Ana:

concepção, avaliador, análise

estatística, orientação

Andréia Pereira de Souza:

coleta dos dados

Lucas Cambiagui:

fotografias 



\section{DEDICATÓRIA}

Dedico este trabalho a minha família. Por vocês consegui superar os obstáculos e chegar até aqui!

Aos meus pais, José Edison e Maria Izabel, Aos meus irmãos Ana Paula e Pedro Isaac, Amo muito vocês! 



\section{AGRADECIMENTOS}

À Deus, por estar sempre presente em minha vida, por nunca me abandonar, por me mostrar que tudo é possível quando se tem fé. Obrigada pela vida maravilhosa que tenho!

Aos meus pais, José Edison e Maria Izabel pelo amor, carinho, apoio e dedicação. Pelas palavras de incentivo nos momentos dificeis, por me mostrarem que tudo tem um propósito na vida! Obrigada por confiarem em mim. Sem vocês este momento não seria possível! Amo muito vocês!

Aos meus irmãos Ana Paula e Pedro, pelo amor, carinho e amizade, por sempre torcerem por mim e me incentivarem! Por saber que sempre posso contar com vocês!

À minha família, tios, avós e primos, pelo carinho, apoio e por torcerem pelo meu sucesso!

À minha orientadora Prof ${ }^{\prime}$. Dr ${ }^{a}$. Adriana Campos Passanezi Sant'Ana, a quem respeito e admiro, não só profissionalmente, mas como pessoa. Obrigada por ter guiado meus passos desde a graduação, pela confiança depositada em mim, pelos ensinamentos e atenção! 



\section{AOS AMIGOS!}

"Abençoados os que possuem amigos, of que os têm sem pedir. Porque amigo não se pede, não se compra, nem se vende.

$$
\begin{gathered}
\text { Amigo a gente sente!" } \\
\text { Machado de Assis }
\end{gathered}
$$

Aos meus queridos amigos Carolina Ortigosa, Bruna Centurion, Aninha, Maria Fernanda, Mariana, Rafael Lara, Roberta Domingues, Bárbara, Clarissa. Obrigada pela amizade sincera! Pessoas que apesar da distância sei que sempre estão torcendo por mim!

À querida amiga Andréia Souza, pela amizade, carinho e ajuda. Poucas pessoas teriam feito o que você fez por mim. Meu eterno agradecimento!

Ao querido amigo Lucas de Vasconcelos! Pela amizade, pelo carinho, por estar ao meu lado esse ano e me ajudar nos momentos difíceis. Obrigada por toda ajuda na realização desse trabalho, seu apoio e incentivo foram muito importantes!

Ao querido amigo Lucas Cambiagui, pela amizade, carinho e ajuda na realização desse trabalho!

Aos amigos de pós graduação Jorge Fiamengui, Fabiola Azevedo, Larissa Pessoa, Lucas Cambiagui, Andréia Souza, Maria Alejandra a convivência com vocês fez as dificuldades serem superadas mais facilmente, muito obrigada!

A todos os colegas de pós graduação, pela amizade e convivência!

Aos queridos amigos, Bela e Serginho pela amizade, confiança e ensinamentos! Vocês são pessoas maravilhosas!

À amiga Denise, sempre alegre e disposta a ajudar. Obrigada pela amizade! 

Aos funcionários do departamento de periodontia:

À amiga Edilaine (Edi), por toda ajuda e amizade, principalmente durante a realização desse trabalho!

Ivânia, Marcela, Marcos (Marcão) obrigada por toda ajuda!

Aos professores da Periodontia, Prof. Dr Euloir Passanezi, Prof ${ }^{a}$ Dr $^{a}$ Adriana

Campos Passanezi Sant'Ana, Prof Dr Sebastião Luis Aguiar Greghi, Prof ${ }^{t}$ $D^{a}{ }^{a}$ Maria Lucia Rubo de Rezende, Prof ${ }^{a}$ Dr $^{a}$ Carla Andreotti Damante, Prof ${ }^{a}$ Dr $^{a}$ Mariana Schutzer Ragghianti Zangrando pela competência, pela generosidade, carinho e por servirem de inspiração para mim!

Às funcionárias da pós graduação, Cleusa e Hebe, pelo carinho, atenção e principalmente paciência! Obrigada por toda ajuda!

À Déborah Blasca, pela disponibilidade e paciência.

Às funcionárias da pós graduação, Fátima, Letícia e Leila por sempre estarem disponíveis para me ajudar!

Às funcionárias do setor de triagem pela colaboração com esta pesquisa!

Agradeço também a todos os pacientes e alunos que contribuíram com esta pesquisa, tornando-a possível de ser realizada!

E a todos que colaboraram direta ou indiretamente ao longo do meu doutorado e na realização deste trabalho.

Meus sinceros agradecimentos,

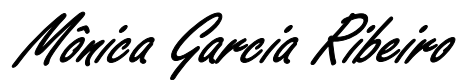



"A persistência é o caminho do êxito." Charles Chaplin 



\section{RESUMO}

A ausência ou perda da papila interdental cria deficiência estética, problemas fonéticos, impactação alimentar e gera muita expectativa ao paciente. Até o momento, o tratamento da ausência ou perda da papila interdental tem sido mal sucedido e não há estudos que indiquem que a regeneração da papila é um resultado previsível. O objetivo deste estudo foi avaliar a efetividade da injeção de gel de ácido hialurônico de origem não animal na redução ou eliminação da deficiência de papila entre dentes naturais comparativamente ao tratamento por meio de enxerto de tecido conjuntivo subepitelial. Foram avaliados neste estudo 20 sítios de 6 pacientes de ambos os sexos, com idade variável de 29 a 62 anos, apresentando deficiência de papila entre dentes naturais, na região anterior superior, em pelo menos dois dentes. Os 20 sítios tratados foram aleatoriamente divididos em dois grupos, de acordo com o tratamento para correção da deficiência de papila por meio de enxerto de tecido conjuntivo subepitelial (grupo controle) ou por meio de injeção de gel de ácido hialurônico (grupo teste). Um examinador único, calibrado, avaliou a distância da ponta da papila ao ponto de contato com auxílio de sonda periodontal milimetrada antes e aos 1, 3 e 6 meses após o tratamento. Além disso, foram investigados, nos sítios tratados, as medidas de profundidade de sondagem, nível de inserção, índice de sangramento do sulco, índice de placa, distância do ponto de contato à crista óssea alveolar, distância da ponta da papila à crista óssea alveolar e largura da papila. Os resultados demonstraram que aos 6 meses de pósoperatório o percentual de mudança na altura da papila foi maior no grupo teste $(14,94 \% \pm$ $21,35 \%)$ do que no grupo controle $(-1,39 \% \pm 31,46 \%)$, entretanto sem diferenças significantes entre os grupos ( $>$ > 0.05). Não houve variação estatisticamente significante na largura da papila antes e aos 4 meses após o tratamento nos grupos teste $(p=0.09)$ e controle $(p=0.16)$, assim como não houve variação significativa na distância entre a ponta da papila e a crista óssea alveolar. Houve melhora significativa do Índice de Estética Rosa (IER) observado aos 6 meses de acompanhamento em comparação com a condição inicial no grupo teste ( $\mathrm{p}=$ 0.0078; Wilcoxon), enquanto que não houve mudança significativa no IER observado no grupo controle aos 6 meses de acompanhamento $(p=0.35)$. Os resultados obtidos permitiram concluir que o tratamento da deficiência de papila por meio de injeção de gel de ácido hialurônico promove melhora da deficiência de papila, similar aos resultados obtidos com o tratamento por meio de enxerto de tecido conjuntivo subepitelial, porém com melhora 

estética significativa relacionada especialmente às características de cor e textura do tecido relativamente aos tecidos moles adjacentes.

Palavras-chave: Ácido Hialurônico, papila dentária, estética. 



\section{ABSTRACT \\ New evaluation technique non-surgical for papilla deficiency treatment in cosmetic area: randomized controlled trial}

The absence or loss of interdental papilla creates an esthetic deficiency, phonetic problems and food impaction and generates a lot of expectation for the patient. Until now, the treatment for absence or loss of interdental papilla is unsuccessful e and there are no researches that show that the papilla regeneration is a predictable outcome. The aim of this study was to evaluate the effectivity of a non-animal originated hyaluronic acid injection in the reduction or elimination of papilla deficiency between natural teeth in comparison to a sub epithelial connective tissue graft treatment. The analysis was made on 20 sites in 6 patients, both genders, 29 - 62 years, showing deficiency in the papilla between natural teeth in the upper anterior region in at least two teeth. The 20 sites treated were randomly divided into two groups, according to the treatment by subepithelial connective tissue graft (control group) or by hyaluronic acid injection (test group). A single calibrated examiner evaluated the distance between the tip of the papilla to the contact point using a graduated periodontal probe before the treatment and 1, 3 and 6 months after it. Besides, it were investigated probing pocket depth, clinical attachment level, gingival bleeding index, plaque index, distance from papilla to alveolar crest, distance from contact point to alveolar crest and width of the papilla. The results showed that 6 months after the procedure, the percentage of change in the papilla level was higher in the test group $(14,94 \% \pm 21,35 \%)$ than in the control group $(-1,39 \% \pm$ $31,46 \%)$, though not statistically significant $(\mathrm{p}>0.05)$. There was no significant difference variation in the width of the papilla before and 4 months after the treatment in test group $(\mathrm{p}=0.09)$ and control group $(\mathrm{p}=0.16)$, and there was no significant difference variation in the distance between the tip of the papilla and the alveolar bone crest. There was significant improvement of the Pink Esthetic Score (PES) after 6 months in comparison to the initial condition in test group ( $\mathrm{p}=0.0078$; Wilcoxon), while there was no significant difference in the PES in control group 6 months after treatment $(\mathrm{p}=0.35)$. The results allow to conclude that the treatment for of the papilla deficiency using hyaluronic acid injection promotes improvement, similar to the results of the sub epithelial connective tissue graft treatment, but with significant esthetic improvement related specially to the color and texture characteristics of the adjacent soft tissues.

Key words: Hyaluronic acid, dental papilla, esthetics. 



\section{LISTA DE ILUSTRAÇÕES}

- FIGURAS

Figura 1 - Diagrama de fluxo do estudo 45

Figura 2 - Aplicação do gel de ácido hialurônico em papila incluída no grupo teste com seringa descartável.

Figura 3 - Fotografias da cirurgia. 48

Figura 4 - Delimitação da área de interesse pela demarcação de linha horizontal tangenciando as bordas incisais (H1) e junção cementoesmalte (H2) dos incisivos lateral e central, unidas por linha vertical (V1) tangenciando o ponto de contato interproximal. Essas linhas de referência foram posicionadas sobre as imagens obtidas nos diferentes períodos pós-operatórios, padronizando o tamanho e posição da imagem, permitindo a análise da área da papila.

Figura 5 - Determinação da área de deficiência de papila no software ImageJ 51

Figura 6 - Determinação da distância entre a ponta da papila e a base do ponto de contato no software ImageJ....

Figura 7 - Variação na altura da papila (eixo Y), definida pela distância PPPC (ponta da papila-ponto de contato) nos diferentes períodos de avaliação (eixo $\mathrm{X}$ ) para o grupo teste (média \pm desvio-padrão; ANOVA para medidas repetidas)

Figura 8 - Variação na altura da papila (eixo Y), definida pela distância PPPC (ponta da papila-ponto de contato) nos diferentes períodos de avaliação (eixo X) para o grupo controle (média \pm desvio-padrão; ANOVA para medidas repetidas) 60 

Figura 9 - Características clínicas da papila interproximal entre os dentes 12 e 13 alocada no grupo teste nos períodos de avaliação clínica inicial (A) e de 1 mês (B), 3 meses (C) e 6 meses (D) de acompanhamento pós-operatório

Figura 10 - Características clínicas da papila interproximal entre os dentes 11 e 12 alocada no grupo controle nos períodos de avaliação clínica inicial (A) e de 1 mês (B), 3 meses (C) e 6 meses (D) de acompanhamento pós-operatório

Figura 11 - Percentual (média \pm desvio-padrão) de mudança na altura da papila interproximal aos 6 meses de acompanhamento comparativamente ao exame inicial (baseline) nos grupos teste e controle $(\mathrm{p}=0.19$; Mann-Whitney)..... 62

Figura 12 - Percentual (média \pm desvio-padrão) da área de deficiência de papila nos grupos teste e controle aos 6 meses de acompanhamento (teste não paramétrico de Mann Whitney

Figura 13 - Percentual (média \pm desvio-padrão) da distância linear ponta da papila-base do ponto de contato nos grupos teste e controle aos 6 meses de acompanhamento (teste não paramétrico de Mann Whitney) 



\section{LISTA DE TABELAS}

Tabela 1 - Índice de estética rosa 54

Tabela 2 - Parâmetros periodontais observados na amostra no exame inicial (boca toda)

Tabela 3 - Largura da papila, distância entre a crista óssea alveolar e base do ponto de contato e distância entre a crista óssea alveolar e a ponta da papila nos grupos teste e controle no exame inicial e aos 4 meses pós-operatório

Tabela 4 - Índice de Papila Modificado (Geurs et al. 2012) observado nos diferentes períodos de avaliação nos grupos teste e controle

Tabela 5 - Análise estatística (teste de Wilcoxon) do Índice de Estética Rosa observado nos grupos teste e controle no exame inicial e aos 6 meses de acompanhamento 66

Tabela 6 - Distância PC-CA, PP-PC no exame inicial e final, percentual de mudança na altura da papila e condição periodontal dos sítios/pacientes incluídos nos grupos teste e controle. 



\section{LISTA DE ABREVIATURA E SIGLAS}

\begin{tabular}{|c|c|}
\hline JCE & Junção amelo-cementária \\
\hline $\mathrm{AH}$ & Ácido Hialurônico \\
\hline IPBT & índice de placa de boca toda \\
\hline TCLE & Termo de consentimento Livre e Esclarecido \\
\hline AltP & altura da papila \\
\hline PP-CA & distância da ponta da papila à crista óssea alveolar \\
\hline PC-CA & distância da base do ponto de contato à crista óssea alveolar \\
\hline PP-PC & distância da ponta da papila ao ponto de contato \\
\hline IP1 & índice de placa \\
\hline IPM & índice de papila modificado \\
\hline IER & índice de estética rosa \\
\hline ISS & índice de sangramento à sondagem \\
\hline MV & mésio-vestibular \\
\hline $\mathrm{CV}$ & centro da face vestibular \\
\hline DV & disto-vestibular \\
\hline ML & mesio-lingual \\
\hline CL & centro da face lingual \\
\hline DL & disto lingual \\
\hline NIC & nível de inserção clínica \\
\hline P.S & Profundidade de sondagem \\
\hline LP & largura da papila \\
\hline
\end{tabular}





\section{SUMÁRIO}

1 INTRODUÇÃO 17

2 REVISÃO DE LITERATURA 23

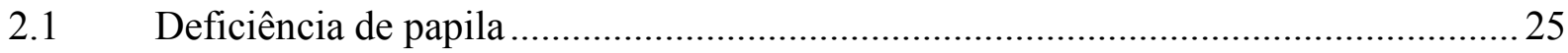

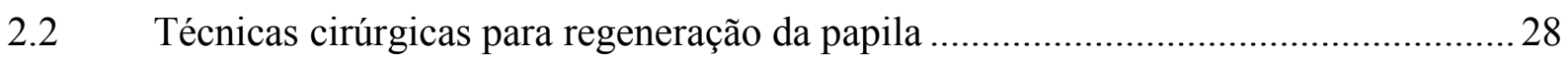

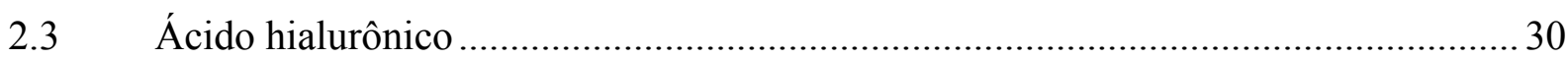

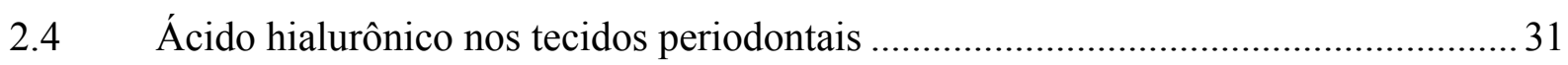

2.5 Uso de ácido hialurônico para o tratamento de ausência ou deficiência de papila

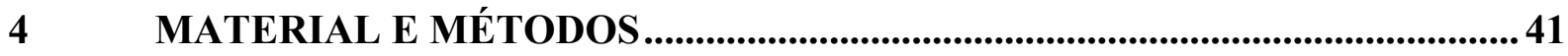

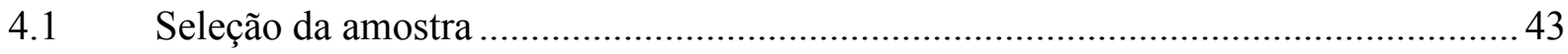

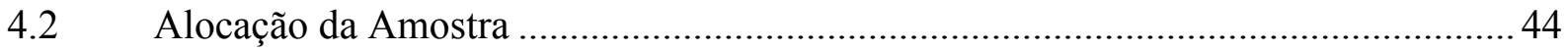

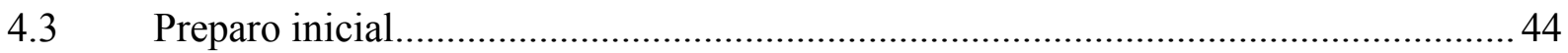

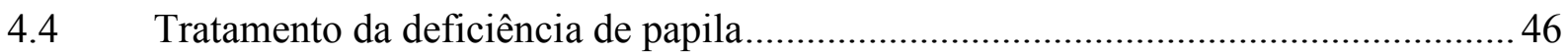

4.4.1 Grupo Teste: tratamento não cirúrgico por meio da aplicação de gel de ácido hialurônico

4.4.2 Grupo Controle: tratamento cirúrgico por meio de enxerto de tecido

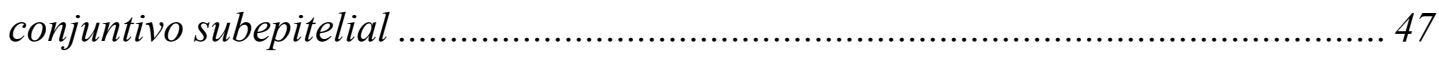

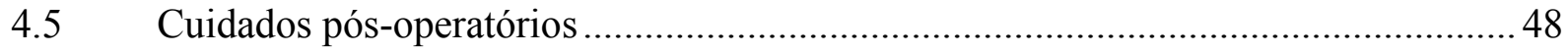

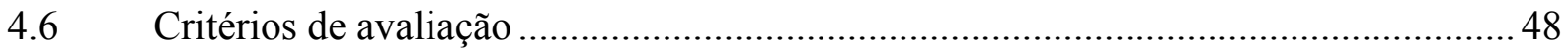

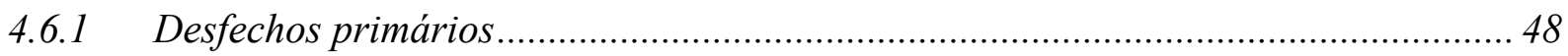

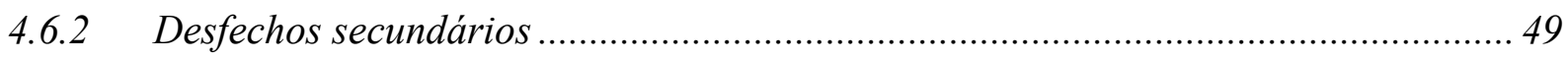

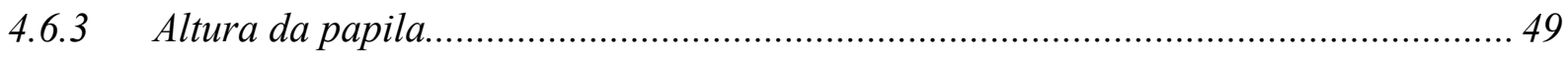

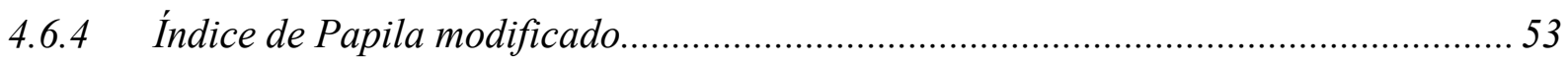

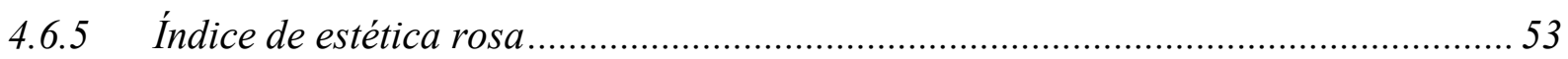

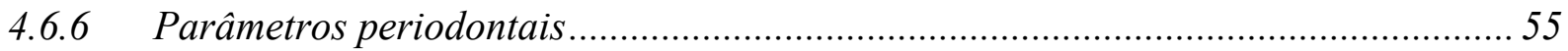

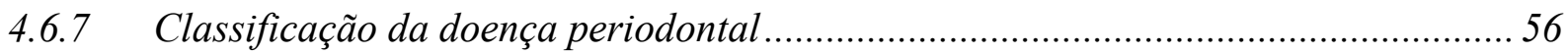



4.7 Análise estatística

.56

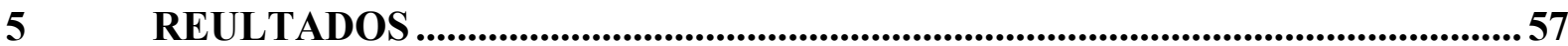

6 DISCUSSÃO

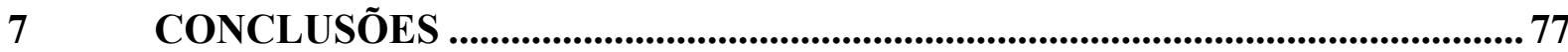

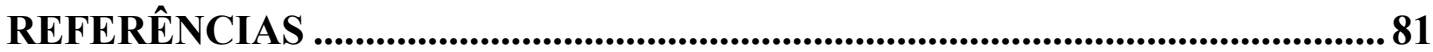

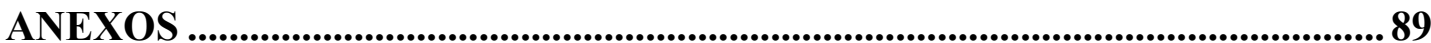



1 INTRODUÇÃO 



\section{INTRODUÇÃO}

Historicamente, o tratamento periodontal visava mais a preservação e restauração da saúde do periodonto do que o resultado estético do tratamento. Assim, apesar do periodontista ser capaz de tratar e manter com sucesso casos de doença periodontal avançada, a estética ficava comprometida, com o alongamento da coroa clínica visível e frequentemente causando o achatamento ou a perda de papila interproximal, formando os chamados "black spaces" (AZZI; ETIENNE; CARRANZA, 1998). Atualmente, os avanços na cirurgia plástica periodontal e a preocupação por resultados estéticos por parte dos pacientes tem desafiado o profissional a devolver a saúde periodontal mantendo ou criando uma condição estética favorável. No entanto, apesar desses avanços, o tratamento cirúrgico realizado para eliminação de bolsa na região anterior pode-se revelar prejudicial com relação à autoestima e confiança de um paciente (INGBER, 1989) por causar a perda da papila interdental.

A papila interdental é a porção gengival que ocupa o espaço entre dois dentes adjacentes (COHEN, 1959). Ela não atua apenas como uma barreira biológica na proteção das estruturas periodontais, mas também exerce um papel crítico na estética. Diversos fatores envolvem a ausência ou perda de papila interproximal, entre eles a disponibilidade de suporte ósseo adjacente; contorno da crista óssea que é o alicerce para o suporte gengival; distância interdental, que deve ter em torno de 3,0mm para assegurar a forma e volume adequados da papila interdental (ZETU; WANG, 2005); dimensão do espaço interproximal (distância do ponto de contato à crista óssea alveolar), que em dentes naturais deve ser $\leq 5 \mathrm{~mm}$ (TARNOW; MAGNER; FLETCHER, 1992). Portanto, a presença ou ausência de papila é influenciada por mais de um fator, sendo a distância do ponto de contato à crista óssea alveolar, o fator mais significante em determinar a presença da papila interdental.

Nordland \& Tarnow, em 1998 (NORDLAND; TARNOW, 1998), classificaram a perda de papila em 3 categorias: Classe I - quando a ponta da papila se encontra entre o ponto de contato e a junção cemento-esmalte (JCE) interproximal (sem aparência visual da JCE); Classe II - presença da ponta da papila no nível ou apical à JCE interproximal, mas coronalmente a JCE vestibular; Classe III - papila se encontra na altura ou abaixo do nível da JCE vestibular. 
A quantidade de papila perdida, a qualidade da mucosa e as características do tecido ósseo subjacente influenciam no prognóstico e plano de tratamento. A ausência ou perda da papila interdental cria deficiência estética, problemas fonéticos, impactação alimentar e gera muita expectativa ao paciente (PRATO et al., 2004). É um dos problemas bucais que mais desafiam o cirurgião dentista e o menos previsível dos tratamentos. Dentre os fatores limitantes ao sucesso do procedimento estão: espaço limitado para acesso cirúrgico, suprimento sanguíneo limitado, posição do dente, forma do espaço interdental, biotipo periodontal e localização da crista óssea (TARNOW; MAGNER; FLETCHER, 1992).

Desta forma, muitas abordagens cirúrgicas e não cirúrgicas foram sugeridas para resolver o problema estético, com diferentes graus de sucesso (EVIAN; CORN; ROSENBERG, 1985; BEAGLE, 1992; HAN; TAKEI, 1996; AZZI; ETIENNE; CARRANZA, 1998; AZZI et al., 1999; PRICE; PRICE, 1999; NEMCOVSKY, 2001; AZZI et al., 2002; TINTI; BENFENATI, 2002). No entanto a maioria dos trabalhos apresenta casos isolados, que contém pouco ou nenhum dado sobre resultados a longo e curto prazo com técnicas específicas (NEMCOVSKY, 2001). Até o momento, o tratamento da ausência ou perda da papila interdental tem sido mal sucedido e não há estudos que indiquem que a regeneração da papila é um resultado previsível (CARDAROPOLI et al., 2004).

A busca por material ideal para aumento dos tecidos moles da face tem sido investigada há muitos anos. Os cirurgiões plásticos e dermatologistas têm um longo histórico de uso de várias substâncias para melhorar a estética em regiões faciais orais (DOVER JS, 2005). Dentro deste contexto, biomateriais injetáveis tem sido utilizados de forma segura e efetiva para correção do contorno facial e, para tanto, devem apresentar as seguintes propriedades: ser biocompatível, não antigênico, não pirogênico, não inflamatório, não tóxico, de fácil uso, estável após a injeção, não migratório, de longa duração, reabsorvível, de aspecto natural e acessível economicamente (ELSON, 1995; DURANTI et al., 1998).

O ácido hialurônico é um bipolímero composto de resíduos alternados de monossacarídeos de ácido D-glucurônico e $\mathrm{N}$-acetilglicosamina ligados em unidades repetitivas, formando um dissacarídeo não sulfatado (PINHEIRO et al., 2005). Apresenta alto peso molecular e forma a matriz extracelular do tecido conjuntivo, não apresentando atividade imunológica celular ou humoral significativa. É amplamente distribuído por todo o corpo e está presente em tecidos conjuntivos da pele, cartilagem, osso e fluido sinovial (LUPTON; ALSTER, 2000; JORDAN, 2003). Essa substância tem capacidade de se ligar à água e formar 
polímeros hidratados de alta viscosidade. Ocorre naturalmente, de forma idêntica, na matriz intercelular de camadas dérmicas da pele de todas as espécies, com alta compatibilidade biológica, o que o torna um candidato ideal para preenchimento tecidual, pois possibilita a redução do potencial para reações imunológicas e rejeição (MATARASSO et al., 2006).

Os efeitos gerais do ácido hialurônico nos tecidos incluem: componente estrutural integrativo da matriz extracelular, regulando o conteúdo de água e a passagem de substâncias para o interstício; interações complexas com componentes da matriz intra e extracelular como resultado de propriedades osmóticas, estereoscópicas e viscoelásticas; efeitos diretos, mediados por receptores, na função celular e, consequentemente, na expressão de genes específicos (GÖTTFERT; STRIEGEL, 2015).

O ácido hialurônico exógeno é rapidamente eliminado da derme e degradado no fígado a dióxido de carbono e água. Produtos de ácido hialurônico não duram mais do que alguns dias na derme e, por isso, não podem ser utilizados em procedimentos para aumento de volume de tecido a não ser na forma modificada, em que o efeito de longa duração pode ser conseguido. As ligações cruzadas realizadas para aumentar o tempo de duração do ácido hialurônico no organismo produzem modificação de suas propriedades estruturais, tornando a substância mais viscosa, densa, de alto peso molecular e insolúvel à água, na forma de gel (DURANTI et al., 1998).

Considerando-se as características que permitem bom preenchimento facial e baixo potencial para reações imunológicas, o ácido hialurônico apresenta-se como um bom candidato ao preenchimento de papilas interproximais deficientes. Alguns estudos investigaram o papel do ácido hialurônico para aumento do volume gengival, como veículo para o transplante autólogo de células fibroblásticas ou como material de preenchimento (PINI PRATO et al., 2000; PRATO et al., 2003; BECKER et al., 2010; GEURS et al., 2012). Os resultados obtidos sugeriram aumento da faixa de gengiva ceratinizada, com formação de tecido ceratinizado completo em curto período de tempo (PINI PRATO et al., 2000; PRATO et al., 2003), redução da deficiência de papila interproximal (BECKER et al., 2010; GEURS et al., 2012) e da recessão gengival (GEURS et al., 2012).

Considerando-se a existência de poucos estudos investigando o papel do ácido hialurônico na reconstrução de papila interdental (BECKER et al., 2010; AWARTANI; TATAKIS, 2015), esse estudo teve por objetivo fundamental avaliar se a aplicação de gel de 
ácido hialurônico de densidade intermediária é efetiva para a criação ou aumento de volume de papila interdental. 
2 REVISÃO DE LITERATURA 



\section{REVISÃO DE LITERATURA}

\subsection{Deficiência de papila}

A papila interdental é a porção gengival que ocupa o espaço entre dois dentes adjacentes (COHEN, 1959). Ela não atua apenas como uma barreira biológica na proteção das estruturas periodontais, mas também exerce um papel crítico na estética.

A perda da papila foi classificada por Nordland \& Tarnow em 1998 em três classes: Classe I - a ponta da papila se encontra entre o ponto de contato e JCE interproximal, sem aparência visual da JCE.

Classe II - a presença da ponta da papila se encontra na ou apical a JCE interproximal, mas coronalmente a JCE vestibular.

Classe III - desaparecimento da papila no ou abaixo do nível da JCE vestibular (NORDLAND; TARNOW, 1998).

Diversos fatores envolvem a ausência ou perda de papila interproximal, entre eles a disponibilidade de suporte ósseo adjacente, o contorno da crista óssea é o alicerce para o suporte gengival. Ochsenbein (1958) descreveu a posição do osso interdental em relação ao osso radicular, chamando de arquitetura positiva. Esse termo se refere à situação na qual a crista óssea segue a forma da junção amelocementária, tem um contorno curvado e o osso interproximal se encontra mais coronal que o osso radicular, encontrando uma distância da junção amelocementaria ao osso alveolar de $2 \mathrm{~mm}$ (OCHSENBEIN, 1958). Essa distância varia de 1-3 mm segundo (GARGIULO, 1961).

A distância interdental é outro fator que influencia a ausência ou perda de papila. Dentes com raízes próximas, onde a distância interdental é menor que $0,5 \mathrm{~mm}$, possuem osso muito fino, que apresentam maior risco de reabsorção, diminuindo a altura de osso interproximal e implicando no desaparecimento da papila (ZETU; WANG, 2005).

Tal (1984) estudou a distância entre as raízes e a prevalência de defeitos infra ósseos, observando a presença desses defeitos apenas quando a distância entre as raízes era maior que 
$3 \mathrm{~mm}$. Assim, uma distância interdental mínima de $3 \mathrm{~mm}$ pode ser necessária para assegurar a forma e volume adequados da papila interdental (TAL, 1984).

Além do nível ósseo e da distância interdental, a dimensão do espaço interproximal (distância do ponto de contato à crista óssea alveolar), é outro fator que interfere na presença de papila. Tarnow et al (1992) verificaram que quando a distância do ponto de contato ao osso alveolar for menor ou igual a $5 \mathrm{~mm}$, a papila está presente em $98 \%$ dos casos, quando a distância for de $6 \mathrm{~mm}$, estará presente em $56 \%$ dos casos e quando a distância for de $7 \mathrm{~mm}$, a papila estará presente em apenas $27 \%$ das vezes. Por isso, concluíram que a altura vertical da base do ponto de contato à crista óssea é fator determinante na manutenção da papila, que em dentes naturais deve ser $\leq 5 \mathrm{~mm}$ (TARNOW; MAGNER; FLETCHER, 1992).

Salama et al (1998) sugeriram uma relação semelhante em terapia com implantes, relacionando a altura do osso interproximal (IHB) com a presença da papila, classificando em três classes. Classe I, IHB é de 4 a $5 \mathrm{~mm}$ (distância do ponto de contato à crista óssea) sugerendo um prognóstico favorável. Classe II, IHB é de 6 a $7 \mathrm{~mm}$ sugerindo um prognóstico cauteloso. Classe III, IHB é $>7 \mathrm{~mm}$ sugerindo um mau prognóstico. Estes dados demonstram que a presença de papila diminui significativamente e a papila não pode ser recuperada quando a distância for superior a $5 \mathrm{~mm}$ em dentes naturais e $3 \mathrm{~mm}$ em implantes. Assim, a altura do osso interproximal determina o nível da papila (SALAMA et al., 1998).

Wu et al (2003), também avaliaram a influencia da distância do ponto de contato à crista óssea alveolar na presença de papila, avaliaram visualmente 200 sítios interproximais de 45 pacientes e consideram a papila presente quando não havia espaço apicalmente ao ponto de contato. A distância do ponto de contato à crista óssea foi realizada através de periapicais padronizadas, seus resultados corroboraram os de Tarnow e colaboradores (WU et al., 2003).

Gastaldo (2004) et al, estudaram o efeito da distância horizontal e vertical entre implantes adjacentes e entre dente e implante, na prevalência da papila interdental. Concluiram que se a distância horizontal tanto entre implantes adjacentes como entre dente e implante for $<3 \mathrm{~mm}$, a papila estará ausente, independente da distância do ponto de contato à crista óssea. Se a distância horizontal for $\geq 3 \mathrm{~mm}$, uma interação entre a distância horizontal e vertical irá influenciar na presença da papila, estando a papila presente quando a distância vertical for de $3 \mathrm{~mm}$ entre implantes e de 3 a $5 \mathrm{~mm}$ entre dente e implante (GASTALDO; CURY; SENDYK, 2004). 
A seguir, Cho et al, avaliaram o efeito da distância horizontal e vertical entre dentes naturais na prevalência da papila. Foram avaliadas 206 papilas, e ela estava $100 \%$ presente quando a distância vertical era de $4 \mathrm{~mm}$ e a distância horizontal variando entre 1,5 a 2,5mm e quando a distância vertical era de $5 \mathrm{~mm}$ e a distância horizontal era de $1,5 \mathrm{~mm}$. Concluíram que as distâncias horizontais e verticais afetam e são dependentes na existência da papila (CHO et al., 2006)

No ano seguinte, Martegani e colaboradores realizaram um trabalho onde foi avaliado clinicamente o comprimento mesio-distal da base da papila e a distância do ponto de contato à ponta da papila. Concluíram que a distância interradicular pode ser considerada uma variável que influencia na forma correta e na harmonia da papila interdental em regiões estéticas. Quando a distância interradicular era maior que $2,4 \mathrm{~mm}$, a variável que representa a distância da crista óssea ao ponto de contato tinha sua influencia diminuída na presença/ausência de papila (MARTEGANI et al., 2007).

Chen et al. (2010) avaliou cada fator individialmente e concluíram que quanto menor a distância do ponto de contato à crista óssea, quanto menor a distância entre dois dentes adjacentes, e quanto menor for a área da ameia, era mais provável da papila interdental estar presente. Porém quando todos os fatores foram avaliados em conjunto, a distância do ponto de contato à crista óssea foi o fator predominante na influência da presença da papila interdental (CHEN et al., 2010).

Gonzalez et al (2011) revisaram os fatores que influenciam a presença da papila interdental e estabeleceram um conceito de casa da papila interdental, sendo ela composta por fatores como a posição do ponto de contato, o contorno da superfície interproximal, o contorno da junção ameolocementária, a distância interdental, a altura da crista óssea e o tecido gengival supra ósseo, que irão determinar a presença de papila (GONZALEZ et al., 2011).

No ano seguinte, Perez et al. (2012), avaliaram clínica e radiograficamente os fatores que influenciam a presença de papila, em seu estudo a distância entre as raízes não influenciaram a ausência de papila, sendo a distância do ponto de contato à crista óssea o fator determinante para a ausência de papila (PEREZ et al., 2012).

Diferentemente desse achado, Kolte et al., e Saxena et al. em 2014, encontraram em seus estudos que as dimensões vertical e horizontal da áreas interproximal tiveram um efeito 
essencial, independente e combinado sobre a existência de papilas interproximais (KOLTE; KOLTE; MISHRA, 2014; SAXENA et al., 2014).

Portanto, a presença ou ausência de papila é influenciada por mais de um fator, sendo à distância do ponto de contato à crista óssea alveolar, o fator mais significante em determinar a presença da papila interdental.

\subsection{Técnicas cirúrgicas para regeneração da papila}

A reconstrução da papila interdental perdida é um dos procedimentos mais difíceis de serem realizados dentro da cirurgia periodontal plástica e reconstrutiva.

Beagle 1992 propôs uma técnica que combina os princípios de técnica de rolo de Abram's com a de preservação de papila de Evian's. Descreveu um caso clínico que se mostrou estável com 4 anos de acompanhamento no qual uma incisão de espessura parcial inicial foi feito na gengiva palatina estendendo um comprimento duas vezes a altura do desejado para reconstrução da papila. O retalho de espessura parcial foi levado para vestibular dobrado sobre si mesmo e suturado (BEAGLE, 1992).

Han e Takei (1996) propuseram uma técnica de reconstrução de papila baseada no uso de incisão semilunar. Uma incisão semilunar foi realizada na mucosa alveolar na região da papila interdental. Uma incisão intra sulcular foi realizada se encontrando a incisão semilunar para permitir a elevação de um retalho de espessura parcial e o deslocamento coronal da unidade gengivopapilar e um enxerto de tecido conjuntivo subepitelial foi colocado sob o retalho. Os autores relataram que o procedimento pode ser repetido uma segunda ou terceira vezes, após 2 a 3 meses de cicatrização para alcançar a meta de reconstrução de papila (HAN; TAKEI, 1996).

Dois anos depois, Azzi e colaboradores publicaram 3 casos clínicos de uma técnica de reconstrução cirúrgica de papila usando um retalho dividido palatino e vestibular com enxerto de tecido conjuntivo. Uma incisão é realizada na vestibular na altura da junção amelocementária, um retalho dividido é confeccionado e a papila é elevada junto com o retalho palatino. O enxerto é removido da área retromolar, como se fosse uma cunha, porém com uma aba de tecido conjuntivo removido do palato, o enxerto é colocado na área receptora 
e os retalhos palatatino e vestibular são suturados sobre o tecido conjuntivo. Concluíram que o sucesso da técnica se dá devido ao suporte sanguíneo dos retalhos (AZZI; ETIENNE; CARRANZA, 1998).

Os mesmos autores em 2001, publicaram uma série de 3 casos clínicos, combinando enxertia óssea com enxerto de conjuntivo para regeneração de papila. Os autores acreditam que a reconstrução do osso interdental é o único e verdadeiro método, estável cirurgicamente de reconstruir a papila perdida em uma área interdental grande. Houve fracasso de um dos casos, atribuído ao tipo de osso utilizado. Concluíram que o sucesso da técnica foi devido ao suprimento sanguíneo do enxerto e fechamento primário do retalho (AZZI et al., 2001).

No mesmo ano, Nemcovsky, demonstrou sucesso em 8 de 10 casos aos 3 meses de acompanhamento utilizando uma técnica para aumento de papila com enxerto conjuntivo através de um retalho palatino. O autor sugere que o procedimento pode ser repetido após vários meses e que a técnica pode ser acompanhada por procedimentos restauradores do contorno proximal dos dentes adjacentes para melhorar os resultados e que mais estudos clínicos e histológicos com acompanhamento em longo prazo são necessários antes que sua previsibilidade possa ser estabelecida (NEMCOVSKY, 2001).

Nordland et al (2008), descreveram uma técnica microcirúrgica para reconstrução da papila interdental. Nos casos apresentados com 3 e 6 anos de acompanhamento concluíram que a microcirurgia aumenta a visibilidade, eliminando incisões desnecessária ou não intencionais, e facilita o acesso, melhorando assim a previsibilidade do processo (NORDLAND; SANDHU; PERIO, 2008).

Sawai e Kohad (2015), propuseram uma técnica semelhante a de Beagle (1992), porém com retalho vestibular. Sugeriram que melhores resultados podem ser obtidos se houver combinação da técnica com o uso de enxertos ósseos ou de tecido conjuntivo (SAWAI; KOHAD, 2012). 


\section{3 Ácido hialurônico}

O ácido hialurônico (AH) foi descoberto por Meyer et al. em 1934 a partir do humor vítreo dos olhos de vacas. É um biopolímero de ocorrência natural que apresenta nenhuma especificidade para o tecido. É um componente essencial da matriz extracelular de todos os tecidos de animais adultos e é especialmente abundante nos embriões precoces (MATARASSO et al., 2006). A estrutura química do AH contém unidades repetitivas de ácido d-glucurônico e $\mathrm{N}$-acetildiglucosamina. É encontrado em quase todos os órgãos vertebrados, mas mais abundantemente na matriz extracelular dos tecidos conjuntivos moles (ROHRICH; GHAVAMI; CROSBY, 2007). Na pele, tem função protetora, de estabilização da estrutura e de absorção do impacto. A quantidade total estimada de AH na pele humana é de aproximadamente 5 gramas, aproximadamente $1 / 3$ da quantidade total de $\mathrm{AH}$ possivelmente existente no corpo humano. As concentrações mais altas de AH são encontradas no cordão umbilical, fluido sinovial e na pele (tecidos conjuntivos moles) e as menores no soro sanguíneo. A maioria das células do corpo são capazes de sintetizar AH na membrana celular por uma proteína ligada à membrana, sendo diretamente secretadas dentro do espaço extracelular. É produzido também por fibroblastos na presença de endotoxinas (DAHIYA; KAMAL, 2013). O hialuronato é altamente hidrofílico e tende a formar conformações estendidas que ocupam um volume enorme em relação a massa; ele forma géis mesmo em concentrações muito baixas. A água atraída para a matriz de ácido hialurônico cria uma pressão, turgor ou inchaço que permite a matriz suportar as forças de compressão. Estas propriedades fazem ácido hialurônico um componente ideal para manter a estrutura adequada e função dos tecidos por meio da criação de volume, lubrificando os tecidos e afetando a integridade celular, a mobilidade e proliferação (MATARASSO et al., 2006). Foi identificada em todos os tecidos periodontais, sendo particularmente proeminente nos tecidos não mineralizados, como gengiva e ligamento periodontal e apenas em pequenas quantidades nos tecidos mineralizados, como osso alveolar e cemento. $\mathrm{O}$ hialuronato presente nos tecidos periodontais tem alto peso molecular e é sintetizado por enzimas hialuronato-sintases (HAS1, HAS2 e HAS3) em várias células presentes nos tecidos periodontais, incluindo fibroblastos e ceratinócitos na gengiva e ligamento periodontal, cementoblastos no cemento e osteoblastos no osso alveolar. O turnover do conteúdo de $\mathrm{AH}$ nos tecidos ocorre por meio de drenagem linfática ou metabolismo local. A eliminação de $85-90 \%$ do $\mathrm{AH}$ presente na corrente sanguínea ocorre no fígado e cerca de $10 \%$ nos rins. $\mathrm{O}$ AH tem funções físiológicas e biológicas importantes, como proliferação celular, reconhecimento e locomoção, contribuindo 
para propriedades de cicatrização. Suas aplicações médicas incluem preenchimento da derme em dermatologia cosmética; prevenção de cicatriz; reparação de feridas; tratamento de osteoartrite e artrite reumatoide; tratamento de catarata e xeroftalmia; scaffold para células tronco mesenquimais; veículo para administração de fármacos (DAHIYA; KAMAL, 2013).

As fontes de ácido hialurônico são: cristas de galo, cordão umbilical, humor vítreo, tendões, pele e culturas bacterianas (GOA; BENFIELD, 1994; DURANTI et al., 1998). Um dos mais conhecidos e utilizados géis de ácido hialurônico disponível comercialmente (Restylane, Q-Med, Suécia) é produzido através de fermentação bacteriana, na concentração de $20 \mathrm{mg} / \mathrm{mL}$, com propriedades viscoelásticas, com baixos níveis de impurezas as quais são incorporadas à estrutura molecular do ácido hialurônica, não tóxicas e não inflamatórias (DURANTI et al., 1998).

As reações adversas ao ácido hialurônico relatadas na literatura foram para aplicações dermatológicas e incluíram reações locais caracterizados por eritema, inchaço, sensibilidade, e hematomas (PINHEIRO et al., 2005). O ácido hialurônico é contraindicado em pessoas que são alérgicas aos produtos avícolas, incluindo frango, ovos, aves ou produtos de aves ou de penas. O fator causal responsável por incitar reações imunes seria a presença de proteínas, embora a carga proteica seja significativamente reduzida (MATARASSO; HERWICK, 2006).

\section{4 Ácido hialurônico nos tecidos periodontais}

Em condições normais, os tecidos gengivais realizam funções típicas de tecidos fibrosos, embora apresentando características muito semelhantes para os tecidos moles. A substância fundamental, que é a estrutura suporte da matriz extracelular, é formada por uma rede altamente estruturada de proteoglicanos em perfeito equilíbrio entre si, fornece aos tecidos gengivais uma consistência firme típica. Neste contexto, o ácido hialurônico desempenha um papel fundamental (PINHEIRO et al., 2005).

O ácido hialurônico foi empregado na Odontologia em técnicas reconstrutivas de tecido mole e tecido duro. Apresentou melhores efeitos bacteriostáticos, de forma geral, no peso molecular de $1300 \mathrm{kD}$, na concentração de $1.0 \mathrm{mg} / \mathrm{ml}$ contra todas as cepas bacterianas testadas, incluindo A. actinomycetencomitans, Prevotella oris, S. aureus e Propionobacterium acnes (PIRNAZAR et al., 1999). 
No periodonto, é considerado como componente essencial na matriz do ligamento periodontal, exercendo importantes papeis na adesão, migração e diferenciação celular mediada por várias proteínas de ligação do $\mathrm{AH}$ e receptores de superfície celular, como CD44. Tem sido estudada como metabólito ou marcador diagnóstico de inflamação no fluido gengival, bem como um fator significante no crescimento, desenvolvimento e reparo dos tecidos (DAHIYA; KAMAL, 2013).

A aplicação do Hialuronato demonstrou-se promissora na cicatrização de feridas em diversas áreas médicas. Desta forma, pensando em conseguir efeitos benéficos semelhantes, Fawzy El-Sayed et al. (2012), estudaram o efeito da aplicação do gel de ácido hialurônico em conjunto com cirurgias periodontais. Os locais que receberam ácido hialurônico mostrou melhoras estatisticamente significativas nos valores de nível de inserção clínica e recessão gengival em 3 e 6 meses em comparação com os sítios controle. Isto pode ser atribuído ao fato do ácido hialurônico facilitar a divisão celular, promovida célula-célula e célula-substrato de adesão, a migração celular, proliferação e ativação, agindo como um armazém e veículo para fatores de crescimento (FAWZY EL-SAYED et al., 2012).

Estudo clínico randomizado realizado para determinar os efeitos de soluções em gel de ácido hialurônico nas variáveis clínicas, composição microbiana subgengival e resposta imune local na cura de feridas após a raspagem e alisamento radicular envolvendo 34 pacientes com periodontite crônica demonstrou que, no grupo onde foi aplicado dois tipos de gel de ácido hialurônico de pesos moleculares diferentes $(n=17)$, houve redução significativamente maior na profundidade de sondagem média e no número de bolsas com profundidade de sondagem $\geq 5 \mathrm{~mm}$ após 3 e 6 meses $(\mathrm{p}<0.05)$ do que nos sítios tratados apenas por meio de raspagem $(\mathrm{n}=17)$. Além disso, 6 meses após a raspagem, as contagens de $T$. denticola reduziram nos dois grupos, enquanto que a contagem de C. rectus diminuiu apenas no grupo teste. Houve aumento das contagens de $P$. intermedia e $P$. gingivalis apenas no grupo controle, confirmando os efeitos bacteriostáticos do ácido hialurônico, bem como na reparação das feridas periodontais (EICK et al., 2013).

Recentemente, o potencial regenerativo de células progenitoras ou células tronco derivadas da margem gengival associada (G-MSCs) com matrix extracelular sintética de ácido hialurônico (HA-sEMC) liberando IL-1ra foi investigado em defeitos cirurgicamente criados em minipigs. Em cada animal, quatro defeitos foram tratados aleatoriamente com IL-1ra/GMSCs/HA-sEMC (teste), G-MSCs/HAsECM (controle positivo), raspagem e alisamento 
radicular (SRP - controle negativo) ou não tratado (controle). Houve maior diferença entre os níveis iniciais e finais (16 semanas) de inserção clínica, profundidade de sondagem, recessão gengival, volume radiográfico de tecido ósseo e sangramento à sondagem no grupo teste, bem como diminuição no comprimento do epitélio juncional comparativamente aos controles negativos, sugerindo potencial regenerativo significativo (FAWZY EL-SAYED et al., 2015).

Bertl et al. (2015) realizaram uma revisão de literatura com o propósito de avaliar o efeito do uso do hialuronato no tratamento de animais ou humanos periodontalmente doentes em associação a terapias cirúrgicas ou não cirúrgicas, quando comparado ao tratamento com essas terapias isoladamente. A maioria dos estudos avaliados descreveram um efeito positivo, porém moderado, a favor do ácido hialurônico como adjuvante das terapias periodontais não cirúrgicas e / ou cirúrgicas com relação a sangramento à sondagem e profundidade de sondagem em comparação aos controles. Com relação ao ganho do nível de inserção clínica no tratamento de defeitos intra-ósseos, não está claro o efeito do Hialuronato quando comparado a terapia cirúrgica isoladamente (BERTL et al., 2015).

\subsection{Uso de ácido hialurônico para o tratamento de ausência ou deficiência de papila}

Pini Prato et al. avaliaram o aumento de volume gengival durante a cirurgia mucogengival usando enxerto de células autólogas veiculadas em gel de ácido hialurônico. Foram tratados sete sítios em seis pacientes, os quais foram acompanhados durante 3 meses. Foram investigados os parâmetros de índice de placa, de sangramento à sondagem, profundidade de sondagem e nível de inserção. A quantidade de gengiva ceratnizada foi medida nos sítios mesial, distal e central de cada dente envolvido. Uma pequena biópsia de gengiva de cada paciente foi removida visando o cultivo de fibroblastos in vitro. Estes foram cultivados sobre "scaffold" composto por ácido hialurônico. A membrana de ácido hialurônico contendo as células cultivadas foi então posicionada para o tratamento dos defeitos mucogengivais nos sítios a serem tratados. Três meses depois da cirurgia, houve aumento da faixa de gengiva ceratinizada, com formação de tecido ceratinizado completo em curto período de tempo, sem desconforto ao paciente (PINI PRATO et al., 2000; PRATO et al., 2003). 
Becker et al. em 2010 avaliaram método para reduzir ou eliminar pequenas deficiências de papilas adjacentes aos dentes ou implantes dentários na zona estética, utilizando gel disponível comercialmente de ácido hialurônico. Os resultados deste estudo piloto foram promissores, sendo possivel melhorar o espaço interdental com gel injetável de ácido hialurônico. Os autores sugerem que seu uso deve ser avaliado em um estudo clínico controlado (BECKER et al., 2010).

Geurs et al. (2012) investigaram a eficácia de enxertos acelulares dérmicos micronizados na regeneração de papila interdental em combinação com técnica cirúrgica minimamente invasiva para maximizar o suprimento sanguíneo à papila interdental atrófica. Foram incluídos no estudo 12 pacientes (10 mulheres e 2 homens) com idade variável entre 40 e 70 anos (média de 55 anos) apresentando 38 papilas deficientes. Os resultados demonstraram diminuição significativa da recessão gengival e aumento significativo do índice de papila após o tratamento, porém com diminuição da faixa de gengiva ceratinizada devido ao posicionamento coronal da margem gengival (GEURS et al., 2012).

No ano seguinte, Mansouri et al. (2014), avaliaram a aplicação clínica de gel de ácido hialurônico para a reconstrução da papila interdental na zona estética. Foram selecionados 11 pacientes com 21 deficiências de papila interdental que atenderam aos critérios de inclusão. Após indução de anestesia local, menos de $0,2 \mathrm{ml}$ de gel de ácido hialurônico foi injetado nas respectivas áreas. Este procedimento foi repetido em 3 semanas e 3 meses após em todas as áreas. Os resultados do estudo demonstraram que a aplicação do gel de ácido hialurônico foi bem-sucedida para a reconstrução de papila interdental, sendo observada uma melhoria superior a $50 \%$ em $43 \%$ dos casos com 6 meses de acompanhamento (MANSOURI et al., 2013).

Ensaio clínico prospectivo foi realizado para avaliar os desfechos clínicos e relacionados ao paciente após a reconstrução de papila interdental na região anterior utilizando gel de ácido hialurônico por Awartani e Tatakis (2015). Foram incluídos no estudo 10 pacientes saudáveis apresentando pelo menos um sítio anterior com perda de papila interdental classe I ou II, os quais foram tratados pela injeção de $0.2 \mathrm{ml}$ de ácido hialurônico diretamente na base da papila. A injeção foi repetida duas vezes depois de 21 dias. Os pacientes foram fotografados para acompanhamento por 6 meses e responderam a questionário de satisfação. Foram tratados 17 papilas (13 na maxila e 4 na mandíbula) em 9 pacientes que completaram o estudo. Houve aumento significativo do volume de papila 
observado da visita inicial até 6 meses após o tratamento, com alto grau de satisfação dos pacientes, que apontaram como ponto negativo o desconforto durante o procedimento (AWARTANI; TATAKIS, 2015).

Segundo Göttfert e Striegel (2015), a ideia fundamental que norteou o uso de ácido hialurônico intraoralmente foi a suposição de que seria possível explorar a estabilidade do ácido hialuronico com ligações cruzadas para diminuir os triângulos negros interdentais. Os autores desenvolveram uma técnica de injeção, denominada de técnica de três passos (TST), a qual pode ser usada na maioria dos casos onde o uso de ácido hialurônico estiver indicado. O objetivo da técnica é criar uma fundação estável para permitr ao corpo regenerar naturalmente, utilizando ácido hialurônico com ligação cruzada. O primeiro passo consiste em injeção de barreira em gel de ácido hialuronico na margem gengival, direcionada ao local onde se deseja aumentar o volume. O segundo passo consiste na injeção dentro da gengiva inserida e o terceiro $2 \mathrm{~mm}$ abaixo do ponto mais alto da papila, para sua estabilização. Foram apresentados três casos clínicos, sendo um para reconstrução de papila interdental necrótica, um para tratamento de periodontite agressiva e outro para reconstrução de papila ao redor de implantes, com melhora clínica dos casos (GÖTTFERT; STRIEGEL, 2015). 

3 PROPOSIÇÃO 



\section{PROPOSIÇÃO}

O objetivo deste estudo é avaliar a efetividade da injeção de gel de ácido hialurônico de origem não animal na redução ou eliminação da deficiência de papila entre dentes naturais comparativamente ao tratamento por meio de enxerto de tecido conjuntivo subepitelial. 

4 Material E MÉTODOS 



\section{MATERIAL E MÉTODOS}

\subsection{Seleção da amostra}

Foram recrutados para este estudo pacientes inscritos para tratamento odontológico na Faculdade de Odontologia de Bauru - Universidade de São Paulo, apresentando deficiência de papila entre dentes naturais na região anterior superior em pelo menos dois sítios. Os critérios de inclusão foram: idade $\geq 18$ anos, saudáveis sistemicamente, com adequado controle de placa (índice de placa de boca toda - IPBT $<20 \%$ ). Foram excluídos do estudo fumantes, grávidas, portadores de doenças sistêmicas debilitantes ou mal controladas (ex.: diabetes mellitus, tumor maligno, imunodeficiências), usuários de medicamentos com influência sobre o periodonto (ex.: bloqueadores dos canais de cálcio, anticonvulsivantes, anticoncepcionais), presença de diastemas na região anterior superior, uso de antibióticos nos três meses precedentes à pesquisa, história de tratamento da deficiência de papila dentro do período de um ano antes do estudo, presença de restaurações na superfície radicular, necessidade de profilaxia antibiótica e aqueles que não aceitaram participar do estudo. Todos os pacientes receberam informações verbais e por escrito quanto aos objetivos e procedimentos da pesquisa e, aqueles que concordaram com a participação, foram selecionados para o estudo, após assinatura do TCLE. O projeto de pesquisa foi aprovado pelo CEP-FOB-USP sob o número 019356/2013, em reunião datada de 24/04/2013.

O recrutamento inicial dos pacientes foi feito no Setor de Triagem da Faculdade de Odontologia de Bauru - USP, no período de julho a outubro de 2013. O exame inicial dos pacientes após o recrutamento foi realizado na Clínica de Periodontia da Faculdade de Odontologia de Bauru - USP, no período de novembro de 2013 a fevereiro de 2014. A alocação dos pacientes aos grupos teste e controle foi realizada em fevereiro de 2014 e os tratamentos foram realizados no período compreendido entre março e maio de 2014. 


\subsection{Alocação da Amostra}

Neste estudo prospectivo, intervencional, modelo de boca dividida, foram tratados 24 sítios em 7 pacientes (Figura 1). A unidade de análise foi o sítio tratado, considerando-se que cada paciente recebeu tratamento pela intervenção teste (aplicação de gel de ácido hialurônico) e controle (enxerto de tecido conjuntivo subepitelial). A alocação dos sítios nos grupos teste $(n=12)$ e controle $(n=12)$ foi feita de forma aleatória, por meio da geração de uma sequência de alocação em computador por indivíduo diferente do operador e do examinador. Essa sequência foi colocada em envelopes selados e opacos, contendo o número do paciente, o sítio e o tratamento a ser realizado. O operador realizou os procedimentos após abertura dos envelopes, imediatamente antes do início do procedimento. Todos os tratamentos foram realizados pelo mesmo operador, o qual passou por fase inicial de treinamento das técnicas não cirúrgica (teste) e cirúrgica (controle) para correção da deficiência de papila, conforme descrito a seguir, em pacientes não incluídos na análise dos dados $(n=2)$.

\subsection{Preparo inicial}

Previamente ao tratamento da deficiência de papila, todos os pacientes foram submetidos a procedimentos de preparo inicial, incluindo raspagem e alisamento radicular, polimento dental, instrução de higiene bucal e correção das discrepâncias e interferências oclusais, quando necessário, como forma de padronização da amostra e a fim de evitar qualquer interferência no resultado do tratamento. 

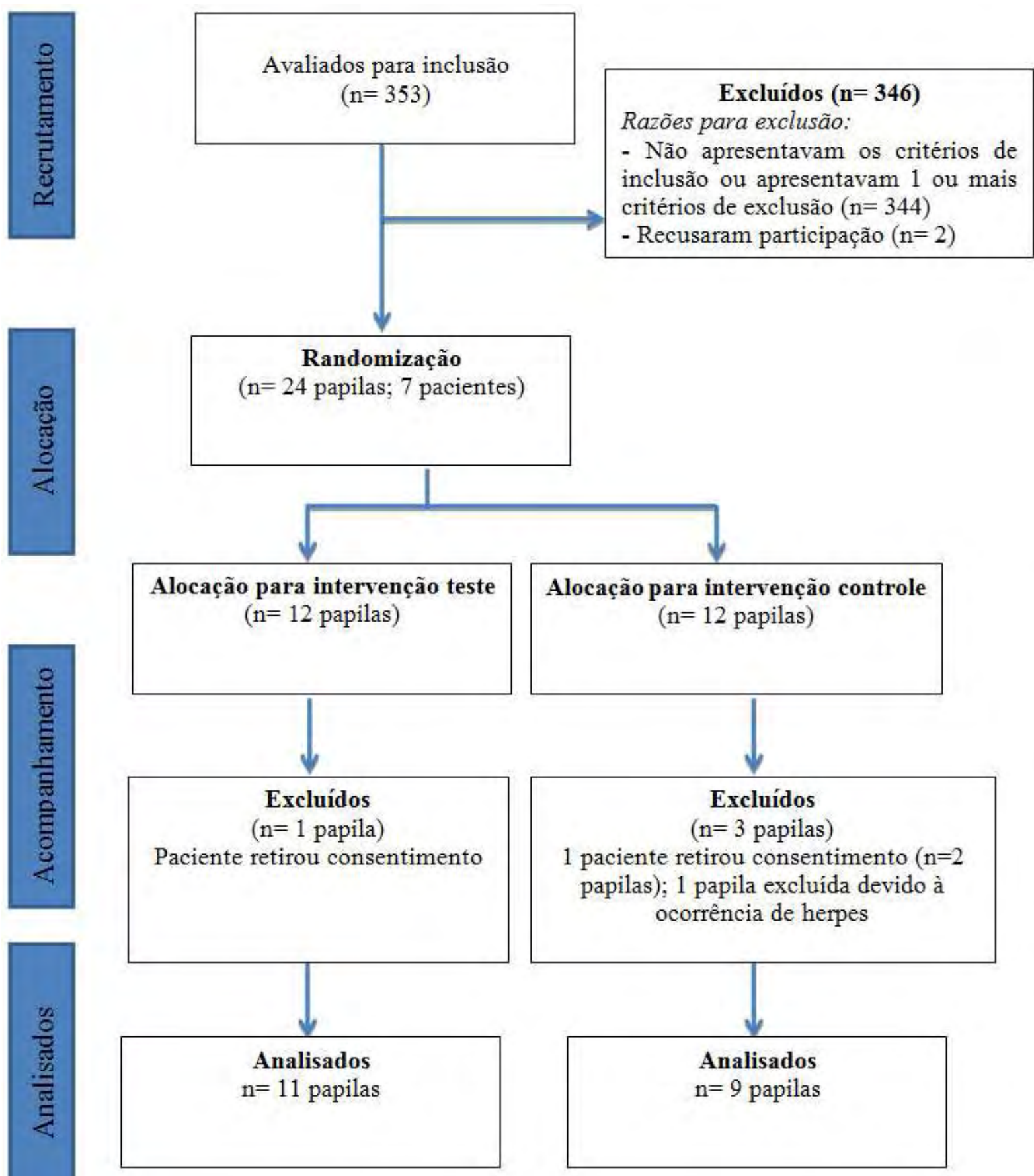

Figura 1- Diagrama de fluxo do estudo 


\subsection{Tratamento da deficiência de papila}

\subsubsection{Grupo Teste: tratamento não cirúrgico por meio da aplicação de gel de ácido}

\section{hialurônico}

Os sítios incluídos no grupo teste foram tratados por técnica não cirúrgica, proposta Becker et al (2010): após anestesia local à distância com anestésico contendo vasoconstritor (Mepiadre 100, DFL, Brasil), dose de até $0.2 \mathrm{~mL}$ de gel de ácido hialurônico disponível comercialmente (Revanesse, Aché, Brasil) foi injetada à distância de 2 a $3 \mathrm{~mm}$ apicalmente à ponta da papila (Figura 2). O gel de ácido hialurônico utilizado é comercializado em seringas para aplicação contendo $1.0 \mathrm{ml}$ da solução. Previamente ao tratamento, as seringas foram subdivididas em seringas descartáveis (seringa de insulina 1ml, Bico Slip Com Agulha 13 x 3,8 - BD) contendo, cada uma, $0.2 \mathrm{~mL}$ da substância, sendo mantidas em geladeira até o uso. Uma vez utilizadas, as seringas foram descartadas em recipiente apropriado para pérfurocortantes. Os pacientes foram orientados com relação à higienização e cuidados no uso do fio dental. Foram monitorados uma vez por semana durante três semanas após o tratamento inicial. Se houvesse permanência do "buraco negro" após as 3 semanas, a injeção de ácido hialurônico foi reaplicada, conforme descrito acima. Esses procedimentos poderiam ser repetidos por até três vezes. Posteriormente, os pacientes foram acompanhados nos períodos de 1, 3, 4 e 6 meses pós-operatórios.

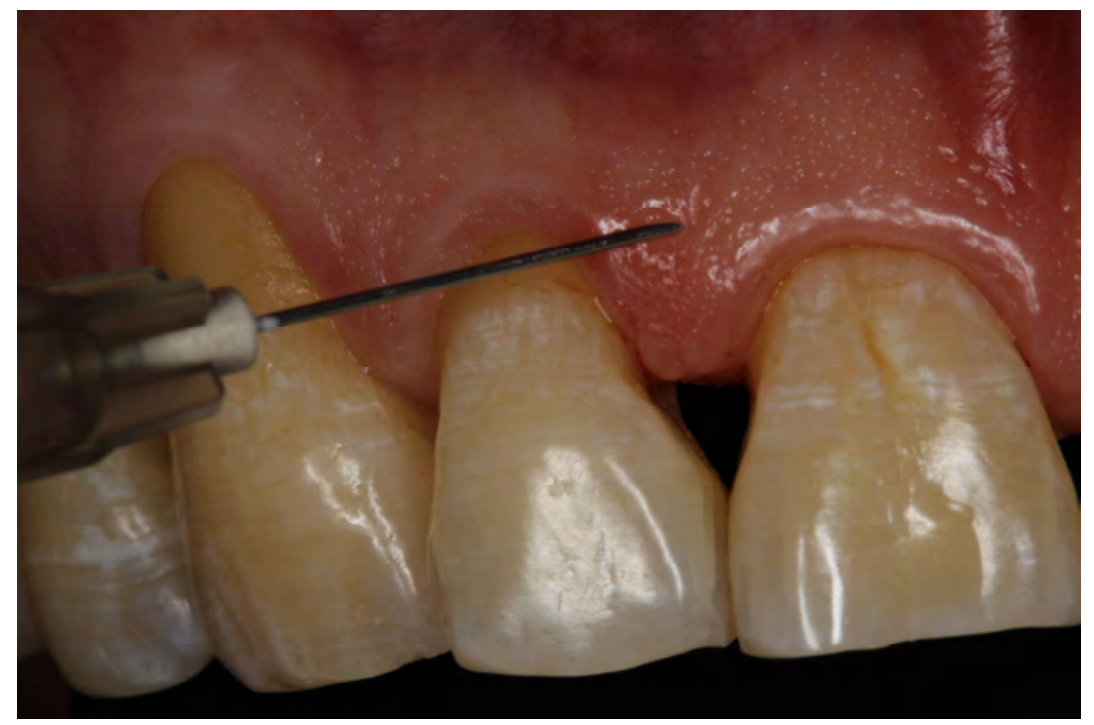

Figura 2- Aplicação do gel de ácido hialurônico em papila incluída no grupo teste com seringa descartável. 


\subsubsection{Grupo Controle: tratamento cirúrgico por meio de enxerto de tecido conjuntivo subepitelial}

Os sítios incluídos no grupo controle foram tratados por meio da realização de enxerto de tecido conjuntivo subepitelial pela técnica descrita por Carnio (2004), relatada a seguir.

Após a administração de anestesia local (Mepiadre 100, DFL, Brasil), foi realizada incisão semilunar $2 \mathrm{~mm}$ coronalmente à junção mucogengival (Figura $3 \mathrm{~A}$ ), na região a ser tratada, se estendendo por toda região dos dentes da papila envolvida. A incisão intrasulcular foi realizada com lâmina 15c (Swann-Morton, Sheffield, Inglaterra) ao redor dos dentes envolvidos, se estendendo da face vestibular à palatina. A papila existente foi completamente preservada. Para separar a papila gengival do osso, a divisão do retalho foi iniciada utilizando o gengivótomo de Orban através da incisão semilunar na face vestibular e estendendo até o palato (Figura 3B). Imediatamente após este procedimento, o tecido conjuntivo obtido do palato na região de pré-molares, de espessura aproximada de $2 \mathrm{~mm}$, foi removido da região do pré-molar e posicionado no espaço criado entre o tecido mole e o tecido ósseo após a divisão do retalho (Figura 3C). O enxerto foi estabilizado em posição com fio de sutura absorvível 60 (Vicryl, Ethicon, Brasil). O tecido gengival foi posicionado coronalmente após divisão do retalho alcançando a área de mucosa alveolar, permitindo a mobilidade dos tecidos sem causar tensão na sutura. $\mathrm{O}$ retalho foi fechado por primeira intenção (Figura 3D). Nenhum cimento periodontal foi colocado na área e nenhuma terapia antibiótica foi administrada.

A medicação pós-operatória prescrita consistiu apenas de anti-inflamatório (Nimesulide, 100mg, b.i.d, 5 dias) e prescrição de bochecho com solução de clorexidina $0,12 \% 2$ vezes ao dia por 4 semanas. $\mathrm{O}$ uso de fio dental foi suspenso na área tratada nos dois primeiros meses após o tratamento e retomado a seguir. 


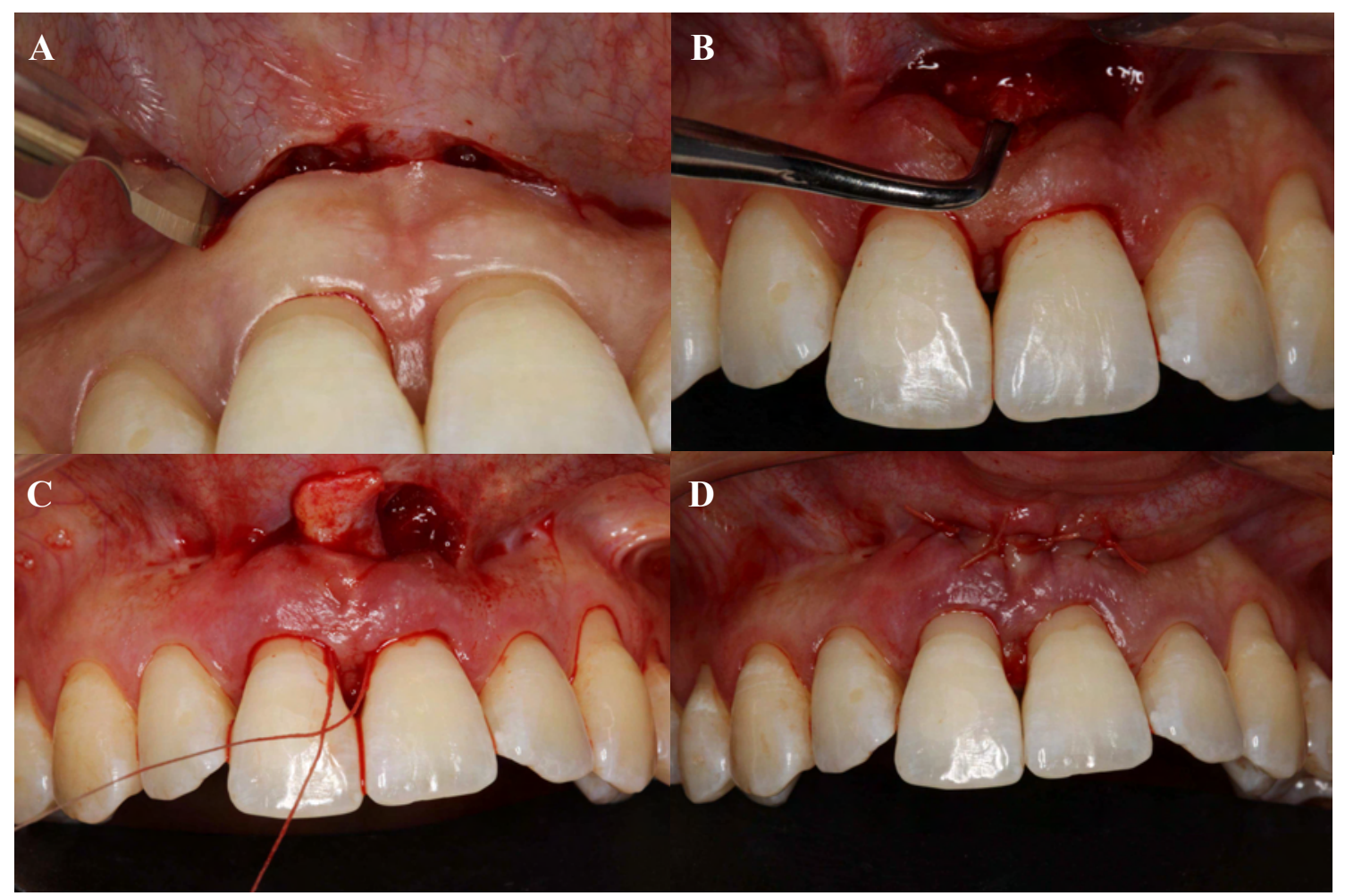

Figura 3- Fotografias da cirurgia. Em (A), incisão semilunar $2 \mathrm{~mm}$ coronalmente à junção mucogengival. Em (B), divisão do retalho utilizando o gengivótomo de Orban. Em (C), posicionamento do tecido conjuntivo no espaço criado entre o tecido mole e o tecido ósseo. Em (D), fechamento do retalho por primeira intenção.

\subsection{Cuidados pós-operatórios}

Todos os pacientes foram acompanhados nos períodos de 1, 3, 4 e 6 meses após o tratamento da deficiência de papila. Nestes períodos, foi realizado controle de placa supragengival por meio de profilaxia profissional, instrução de higiene bucal e, se necessário, nos períodos de 3, 4 e 6 meses, controle de placa subgengival por meio de raspagem e alisamento radicular.

\subsection{Critérios de avaliação}

\subsubsection{Desfechos primários}

No exame inicial e nos exames pós-operatórios, os sítios tratados foram examinados clinicamente, os defeitos mensurados e as imagens fotográficas foram obtidas, conforme posteriormente descrito. O desfecho primário foi a mudança na altura da papila (AltP) aos 6 
meses de acompanhamento, identificada pela medida da distância entre a ponta da papila interproximal e a base do ponto de contato para cada sítio analisado. O percentual de mudança da papila foi determinado por meio da fórmula:

$$
\% A l t P=100-\frac{(\text { altura final } \times 100)}{\text { altura iniaial }}
$$

(onde \%AltP-percentual de altura da papila)

\subsubsection{Desfechos secundários}

Os desfechos secundários incluíram mudanças nos seguintes parâmetros clínicos aos 4 meses pós-operatórios: distância da ponta da papila à crista óssea alveolar (PP-CA); distância da base do ponto de contato à crista óssea alveolar (PC-CA); profundidade de sondagem; comprimento da papila interproximal; índice de papila modificado (IPM); índice de estética rosa (IER); índice de sangramento à sondagem (ISS).

A distância da ponta da papila à base do ponto de contato foi medida com sonda periodontal milimetrada e por meio da análise das fotografias digitais. A distância da base do ponto de contato à crista óssea alveolar foi medida com sonda periodontal milimetrada, sob anestesia local, por meio de sondagem óssea. A distância da ponta da papila à crista óssea alveolar foi calculada por meio da subtração da distância da ponta da papila à base do ponto de contato da distância entre a base do ponto de contato à crista óssea alveolar. $\mathrm{O}$ comprimento interproximal da papila foi medido por meio de sonda periodontal, a partir da altura mesial à altura distal do contorno de tecido interproximal. Todas as medidas clínicas foram obtidas por examinador único, diferente do operador, previamente calibrado e cegado em relação aos tratamentos realizados.

\subsubsection{Altura da papila}

Fotografias intrabucais foram obtidas de todos os pacientes previamente ao tratamento e nos acompanhamentos pós-operatórios de 1, 3 e 6 meses, utilizando a mesma câmera digital (Canon, EOS, Rebel T1i, China). Todos os parâmetros da câmera foram mantidos constantes para obtenção das imagens fotográficas, bem como as condições de iluminação e posição do paciente na cadeira. Os pacientes permaneceram sentados, eretos, com plano de Frankfort 
paralelo ao solo e a câmera foi posicionada com o longo-eixo na horizontal (paralelo ao solo). As imagens foram obtidas de cada sítio de tratamento em posição frontal.

Para análise das dimensões da papila, dois pontos bem visíveis na borda incisal dos dentes na área de interesse foram escolhidos e uma linha foi traçada conectando os dois pontos (H1). Outros dois pontos foram delimitados e uma linha tangenciando a junção cemento-esmalte dos dois dentes adjacentes à papila interproximal de interesse foi delimitada (H2). Outra linha unindo as duas linhas horizontais traçadas (incisal e cervical), passando pelo ponto de contato interproximal, foi desenhada (V1). Essas linhas de referência foram utilizadas para padronização da posição e tamanho das imagens analisadas nos diferentes períodos de tempo (Figura 4).

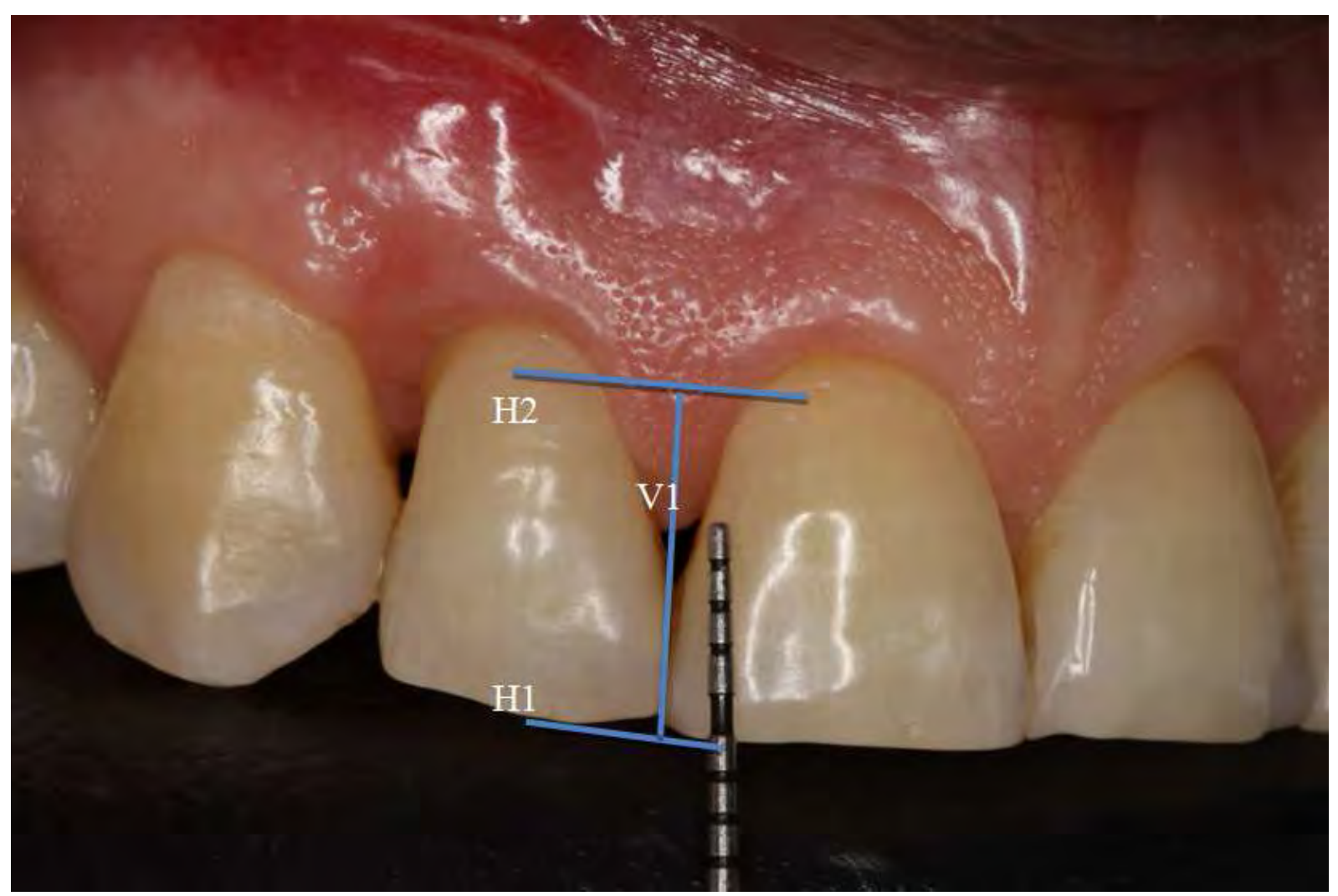

Figura 4- Delimitação da área de interesse pela demarcação de linha horizontal tangenciando as bordas incisais (H1) e junção cemento-esmalte (H2) dos incisivos lateral e central, unidas por linha vertical (V1) tangenciando o ponto de contato interproximal. Essas linhas de referência foram posicionadas sobre as imagens obtidas nos diferentes períodos pós-operatórios, padronizando o tamanho e posição da imagem, permitindo a análise da área da papila. 
As imagens fotográficas foram utilizadas para medir a área da papila perdida antes e depois do tratamento, usando software de análise de imagens (ImageJ, NIH, USA). As imagens foram importadas para o programa, após calibração das mesmas no software Adobe Photoshop (Adobe Inc., EUA). A área da deficiência de papila foi determinada a partir da mensuração da área do triângulo negro existente antes e nos diferentes períodos de tempo após o tratamento, após estabelecimento da escala para padronização das imagens (Figura 5). A distância entre a base do ponto de contato e a ponta da papila foi determinada posicionando-se uma linha vertical perpendicular ao ponto de contato e à ponta da papila (Figura 6).

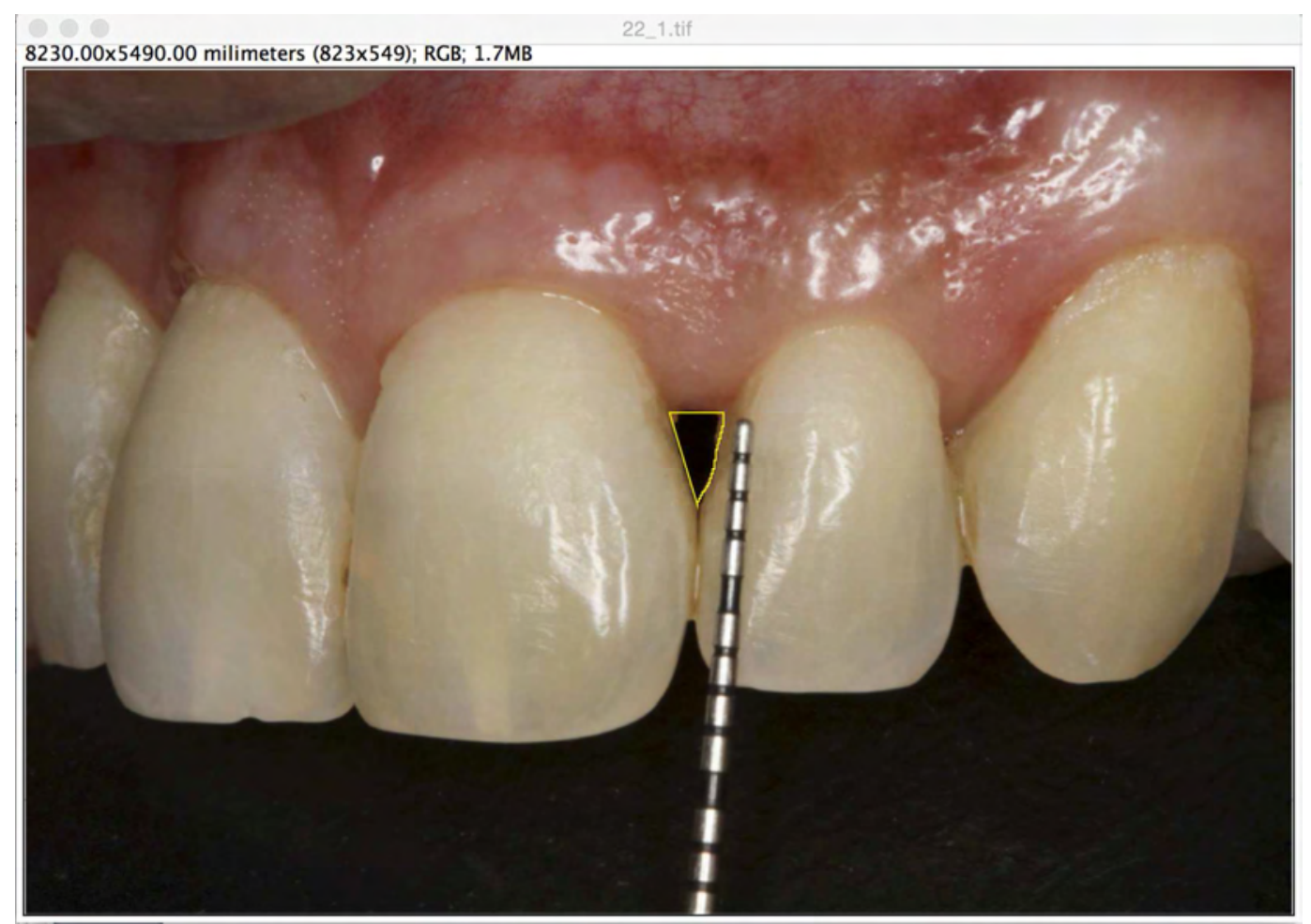

Figura 5- Determinação da área de deficiência de papila no software ImageJ 


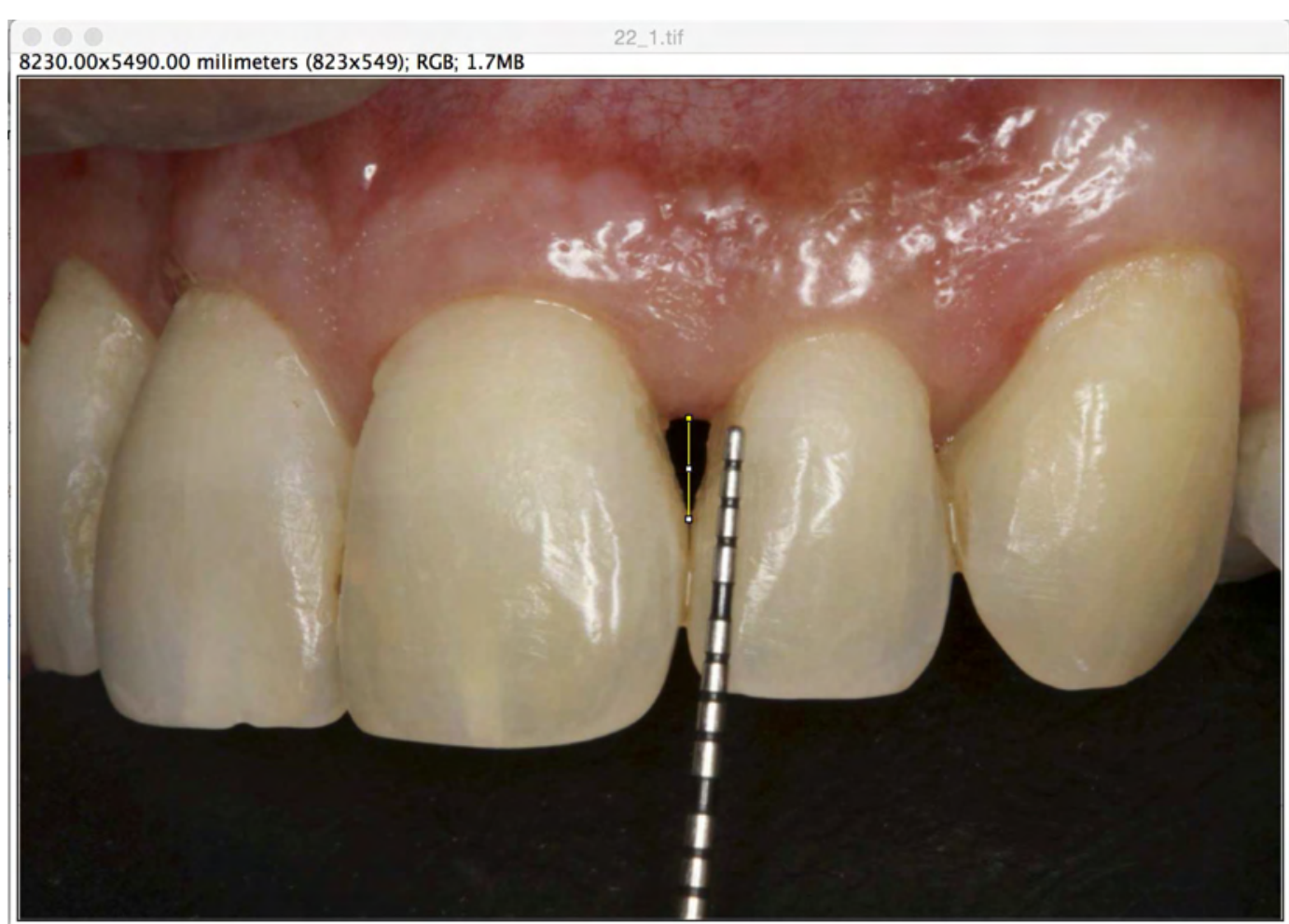

Figura 6- Determinação da distância entre a ponta da papila e a base do ponto de contato no software ImageJ

A área de papila perdida foi mensurada em pixels $/ \mathrm{mm}^{2}$, enquanto que a distância linear entre a ponta da papila e a base do ponto de contato foi mensurada em pixels $/ \mathrm{mm}$. O percentual de variação da altura da papila nas imagens fotográficas (respectivamente, área e distância linear entre a ponta da papila e a base do ponto de contato) foi determinada de acordo com a fórmula:

$$
\% \text { área }=\frac{(\text { area final }- \text { area intcial })}{\text { área inicial }} \times 100
$$

$\mathrm{E}$

$\%$ distância linear $=\frac{(\text { distancia final }- \text { distancia inicial })}{\text { distancia incial }} \times 100$ 


\subsection{4 Índice de Papila modificado}

As papilas foram classificadas, a partir das imagens fotográficas antes e depois do tratamento, de acordo com o Índice de Papila modificado (GEURS et al. 2012), o qual indica cinco níveis diferentes de quantidade de papila presente:

0- Nenhuma papila presente;

1- Menos da metade da altura da papila presente;

2- Pelo menos metade da altura da papila presente, não alcançando a base do ponto de contato entre os dentes;

3- Papila preenchendo todo o espaço interproximal, em boa harmonia com os tecidos adjacentes e ótimo contorno de tecido mole;

4- Papila hiperplásica, com excesso de tecido presente.

As imagens fotográficas foram projetadas para análise por investigador único, previamente calibrado $(K a p p a=0.81 ; \mathrm{p}<0.05)$. A calibração foi realizada por meio da projeção de imagens fotográficas de 7 pacientes diferentes, não identificados, obtidas da região anterior superior, em dois diferentes períodos de avaliação, com intervalo entre os mesmos de 7 dias. No ensaio de calibração do examinador, foram investigados o índice de papila modificado e o índice de estética rosa, descrito a seguir.

\subsection{5 Índice de estética rosa}

Os sítios tratados foram categorizados antes e depois do tratamento de acordo com o índice de estética rosa (FURHAUSER et al., 2005), descrito na Tabela 1 a seguir: 
Tabela 1- Índice de estética rosa

\begin{tabular}{|c|c|c|c|}
\hline & $\mathbf{0}$ & 1 & 2 \\
\hline $\begin{array}{l}1 . \\
\text { Papila mesial }\end{array}$ & Ausente & Incompleta & Completa \\
\hline $\begin{array}{l}2 . \\
\text { Papila distal }\end{array}$ & Ausente & Incompleta & Completa \\
\hline $\begin{array}{l}3 . \\
\text { Nível da margem de } \\
\text { tecido mole* }\end{array}$ & $\begin{array}{l}\text { Grande discrepância } \\
\qquad(<2 \mathrm{~mm})\end{array}$ & $\begin{array}{l}\text { Pequena discrepância } \\
\qquad(1-2 \mathrm{~mm})\end{array}$ & $\begin{array}{l}\text { Sem discrepância }(< \\
1 \mathrm{~mm})\end{array}$ \\
\hline $\begin{array}{l}4 . \\
\text { Contorno de tecido } \\
\text { mole* }\end{array}$ & Pouco natural & Próxima ao natural & Natural \\
\hline $\begin{array}{l}5 . \\
\text { Processo alveolar* }\end{array}$ & Grande deficiência & Leve deficiência & Nenhuma deficiência \\
\hline Cor do tecido mole* & Grande discrepância & Pequena discrepância & $\begin{array}{l}\text { Nenhuma discrepância } \\
\text { Nenhuma discrepância }\end{array}$ \\
\hline $\begin{array}{l}\text { Textura do tecido } \\
\text { mole* }\end{array}$ & Grande discrepância & Pequena discrepância & \\
\hline
\end{tabular}

* em relação ao dente de referência 


\subsubsection{Parâmetros periodontais}

As medidas de profundidade de sondagem, nível de inserção clínica, sangramento à sondagem e índice de placa foram investigados nos períodos pré e pós-operatórios por examinador único, previamente calibrado, cegado em relação aos tratamentos realizados. A mensuração da profundidade de sondagem foi realizada com sonda periodontal milimetrada posicionada paralelamente ao longo eixo do dente e foi determinada pela distância entre a margem gengival e o fundo do sulco ou bolsa, identificada por meio de resistência do tecido à introdução suave da sonda, em seis sítios (mésio-vestibular - MV, centro da face vestibular $\mathrm{CV}$, disto-vestibular - DV, mésio-lingual - ML, centro da face lingual - CL e disto lingual DL) de cada dente presente na cavidade bucal, com exceção dos $3^{\circ}$ molares.

$\mathrm{O}$ índice de sangramento à sondagem foi realizado de acordo com a proposta de Ainamo e Bay (1975) (AINAMO; BAY, 1975), em seis sítios de cada dente presente na cavidade bucal, com exceção dos terceiros molares. A presença de sangramento à sondagem até 15 segundos após a remoção da sonda do interior do sulco foi anotada em ficha clínica com o valor de 1 quando presente e 0 quando ausente.

Foram medidas recessão e hiperplasia gengival, correspondendo à distância entre a margem gengival e a junção cemento-esmalte, sendo anotadas na ficha clínica com sinal positivo e negativo, respectivamente. A partir das medidas de profundidade de sondagem, recessão e hiperplasia, foi determinado o nível de inserção clínica, definido pela distância entre a junção cemento-esmalte e o fundo de sulco ou bolsa, em seis sítios de cada dente presente na cavidade bucal, com exceção dos terceiros molares, de acordo com a fórmula:

$$
N I C=P S-H I P E R P L A S I A
$$

ou

$$
N I C=P S+R E C E S S A ̃ O
$$

onde NIC= nível de inserção clínica; PS- profundidade de sondagem

O índice de placa foi investigado em quatro sítios/dente, de acordo com a proposta de O'Leary et al. (1972)(O'LEARY; DRAKE; NAYLOR, 1972) após o uso de solução evidenciadora de placa. A presença de placa nas faces MV, V, DV e L foi anotada na ficha clínica com o valor 1 e sua ausência como 0 . Essas análises foram realizadas no início do tratamento. 


\subsubsection{Classificação da doença periodontal}

A classificação de periodontite nos pacientes foi determinada de acordo com os critérios de definição de doença periodontal sugeridos pelo Centro de Controle de Doenças (Centers of Disease Control- CDC) em parceria com a Academia Americana de Periodontia (AAP) para investigação epidemiólogica da doença periodontal (Page e Eke, 2007; Eke et al. 2012):

- Periodontite severa: presença de 2 ou mais sítios interproximais com NIC $\geq 6 \mathrm{~mm}$ em dentes diferentes e 1 ou mais sítios interproximais com P.S. $\geq 5 \mathrm{~mm}$.

- Periodontite moderada: presença de 2 ou mais sítios interproximais com NIC $\geq$ $4 \mathrm{~mm}$ (em dentes diferentes) ou 2 ou mais sítios interproximais com PS. $\geq 5 \mathrm{~mm}$ (também em dentes diferentes);

- Periodontite leve: presença de 2 sítios interproximais ou mais com NIC $\geq 3 \mathrm{~mm}$ (em dentes diferentes) e 2 ou mais sítios com PS. $\geq 4 \mathrm{~mm}$ ou 1 sítio com PS. $\geq 5$ mm.

\subsection{Análise estatística}

A análise estatística foi realizada no software GraphPad Prism 6.0 para Mac. Os dados obtidos foram comparados entre os grupos por meio de teste $t$, para as variáveis paramétricas (profundidade de sondagem, nível de inserção, PP-CA, PC-CA, altura da papila) e por meio de Kruskal-Wallis para as variáveis não paramétricas (ISS, IP1, IPM, IER, percentual de mudança na altura da papila, percentual de área de deficiência de papila, percentual de distância linear PP-PC), em cada período de avaliação. Os resultados intra-grupos obtidos nos diferentes períodos de tempo de avaliação foram investigados por meio de análise de variância múltipla para medidas repetidas, complementada pelo teste de Tukey e Mann Whitney para variáveis paramétricas e por meio do teste de Wilcoxon para variáveis não paramétricas. Em todas as análises, foi adotado nível de significância de 5\% $(\alpha=0.05)$. 
5 RESULTADOS 



\section{RESULTADOS}

Foram inicialmente tratadas 24 papilas em 12 pacientes, sendo 12 no grupo teste e 12 no grupo controle. No entanto, um paciente desistiu de participar do estudo após a realização das intervenções iniciais e uma papila foi excluída da análise em decorrência de desenvolvimento de herpes e prejuízo ao resultado do tratamento. Assim, foram analisadas 11 papilas no grupo teste e 9 no grupo controle. Assim, a amostra final foi composta por 21 sítios de tratamento, tratados por meio de injeção de gel de ácido hialurônico $(n=11)$ ou enxerto de tecido conjuntivo pela técnica descrita por Carnio (2004), conforme descrito na Figura 1, em modelo de boca dividida em 6 pacientes (4 homens, 2 mulheres) com idade variável entre 29 e 62 anos $(49,33 \pm 12,51)$.

Os parâmetros periodontais investigados previamente ao tratamento estão descritos na Tabela 2. Previamente à realização do tratamento para correção da deficiência de papila, todos os pacientes receberam tratamento periodontal básico, consistindo de raspagem e alisamento sub e supragengival, polimento dental, instrução de higiene bucal, eliminação dos fatores de retenção de placa e correção das discrepâncias ou interferências oclusais, de forma que, no momento do tratamento da deficiência de papila, os sítios a serem tratados não apresentassem placa ou sangramento gengival presentes e o índice de placa e sangramento gengival de boca toda fosse inferior a $20 \%$. Os parâmetros periodontais referentes aos sítios tratados estão descritos no Anexo I.

Tabela 2- Parâmetros periodontais observados na amostra no exame inicial (boca toda)

\begin{tabular}{lc}
\hline & Média \pm desvio-padrão \\
\hline P.S. & $2,04 \pm 0,25$ \\
NIC & $1,47 \pm 0,88$ \\
ISS & $0,16 \pm 0,17$ \\
IPI & $0,16 \pm 0,25$ \\
\hline
\end{tabular}

\section{Variação na altura da papila}

O desfecho primário foi definido como a mudança na altura da papila aos 6 meses pósoperatório, sendo determinada pela distância entre a ponta da papila interproximal e a base do 
ponto de contato (PP-PC). A análise por meio de análise de variância múltipla para medidas repetidas não mostrou diferenças significantes $(p>0.05)$ antes e depois do tratamento nos grupos teste (Figura 7) e controle (Figura 8).

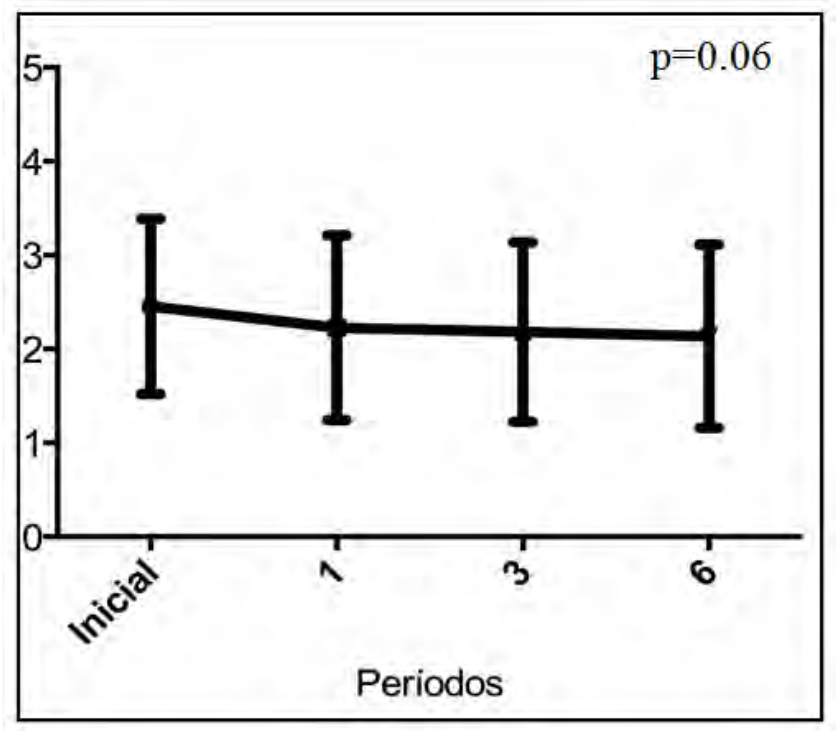

Figura 7- Variação na altura da papila em mm (eixo Y), definida pela distância PP-PC (ponta da papila-ponto de contato) nos diferentes períodos de avaliação (eixo X) para o grupo teste (média \pm desvio-padrão; ANOVA para medidas repetidas)

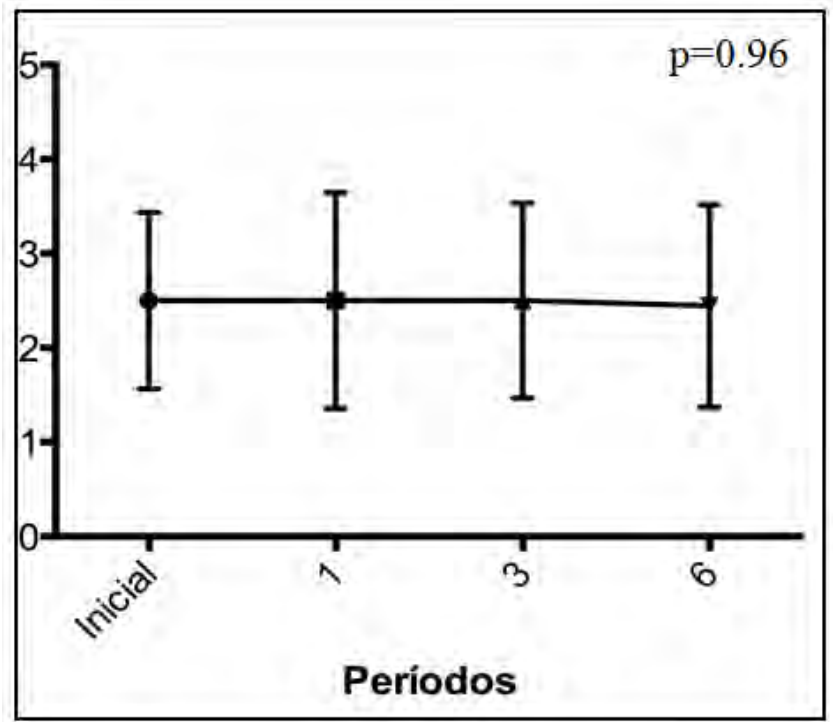

Figura 8- Variação na altura da papila em mm (eixo Y), definida pela distância PP-PC (ponta da papila-ponto de contato) nos diferentes períodos de avaliação (eixo X) para o grupo controle (média \pm desvio-padrão; ANOVA para medidas repetidas)

Nas Figuras 9 e 10 observa-se as imagens clínicas de sítio tratado, respectivamente, no grupo teste e no grupo controle. 

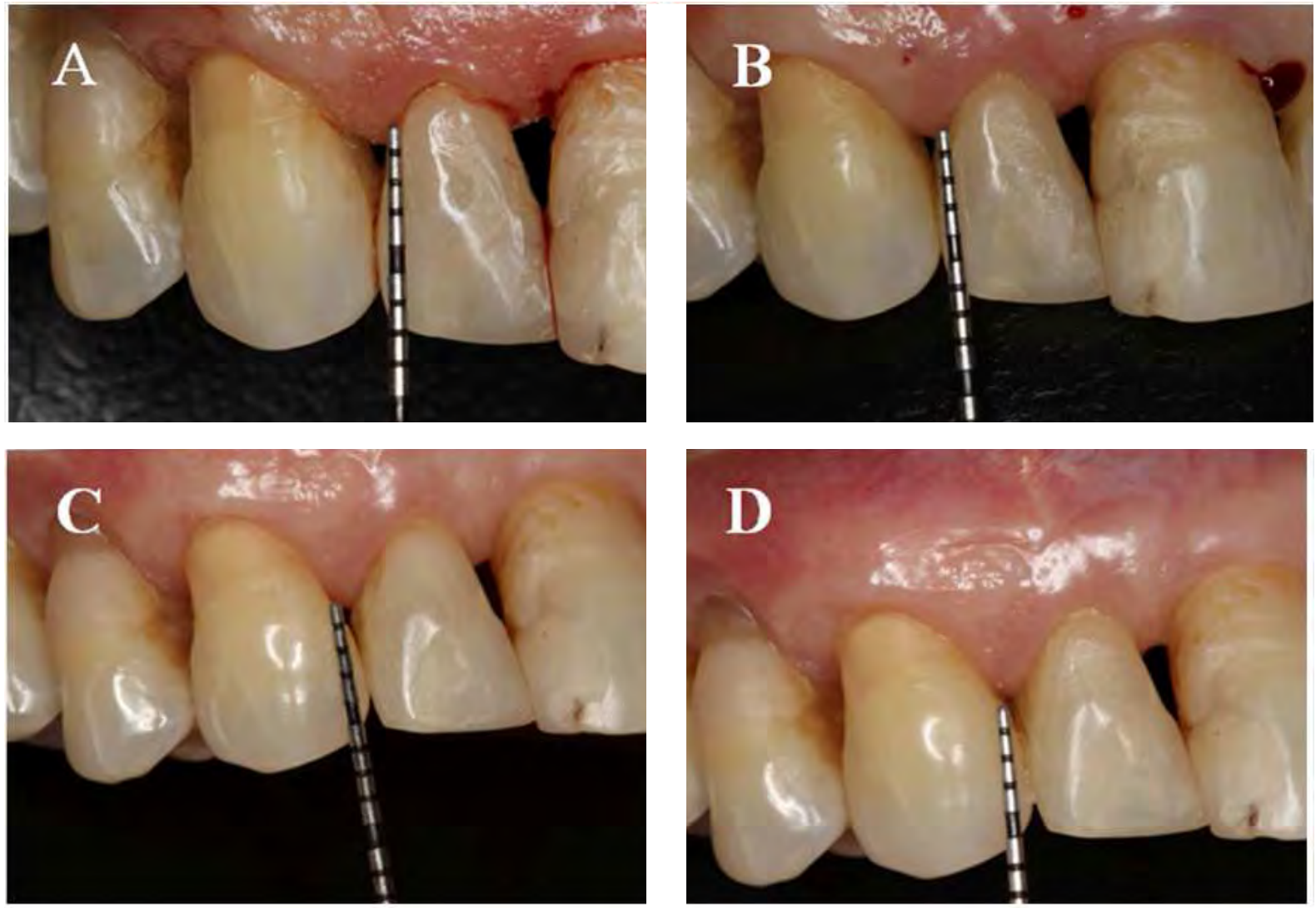

Figura 9 - Características clínicas da papila interproximal entre os dentes 12 e 13 alocada no grupo teste nos períodos de avaliação clínica inicial (A) e de 1 mês (B), 3 meses (C) e 6 meses (D) de acompanhamento pósoperatório
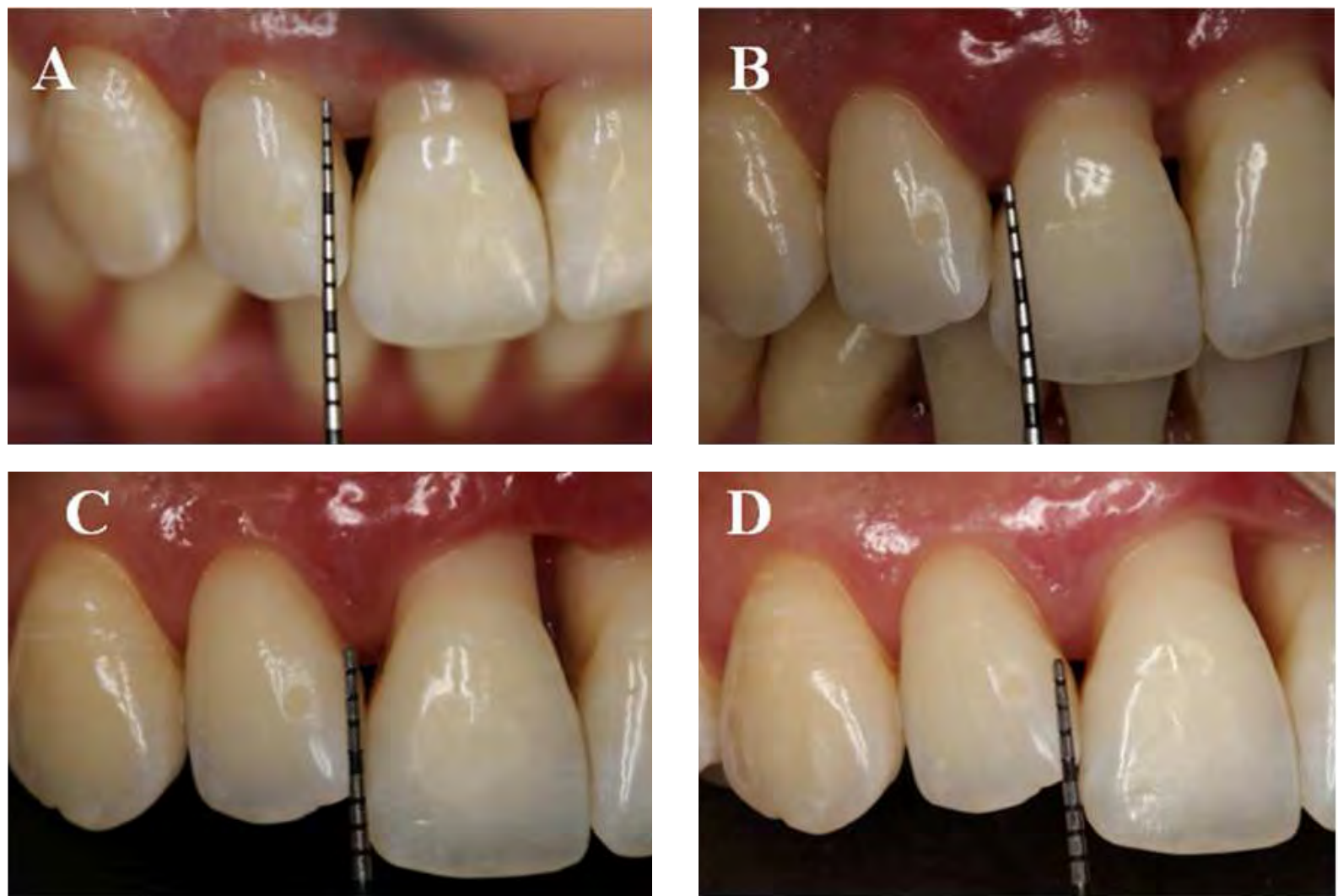

Figura 10 - Características clínicas da papila interproximal entre os dentes 11 e 12 alocada no grupo controle nos períodos de avaliação clínica inicial (A) e de 1 mês (B), 3 meses (C) e 6 meses (D) de acompanhamento pósoperatório 
O percentual de mudança na altura da papila foi maior no grupo teste $(14,94 \% \pm$ $21,35 \%)$ do que no grupo controle $(-1,39 \% \pm 31,46 \%)$, entretanto sem diferenças significantes entre os grupos, segundo o teste não paramétrico de Mann-Whitney $(\mathrm{p}=0.19)$, conforme demonstrado na Figura 11. Dos 11 sítios incluídos no grupo teste, 5 (45,45\%) apresentaram ganho de altura na papila e $6(54,55 \%)$ não apresentaram mudanças na altura da papila, definida como a distância entre a ponta da papila e a base do ponto de contato, relativamente ao exame inicial (baseline). Dos 9 sítios incluídos no grupo controle, 3 (33,33\%) apresentaram ganho na altura da papila aos 6 meses de tratamento, enquanto outros 2 $(22,22 \%)$ não mostraram variação na altura da papila e $4(44,45 \%)$ apresentaram diminuição da altura da papila.

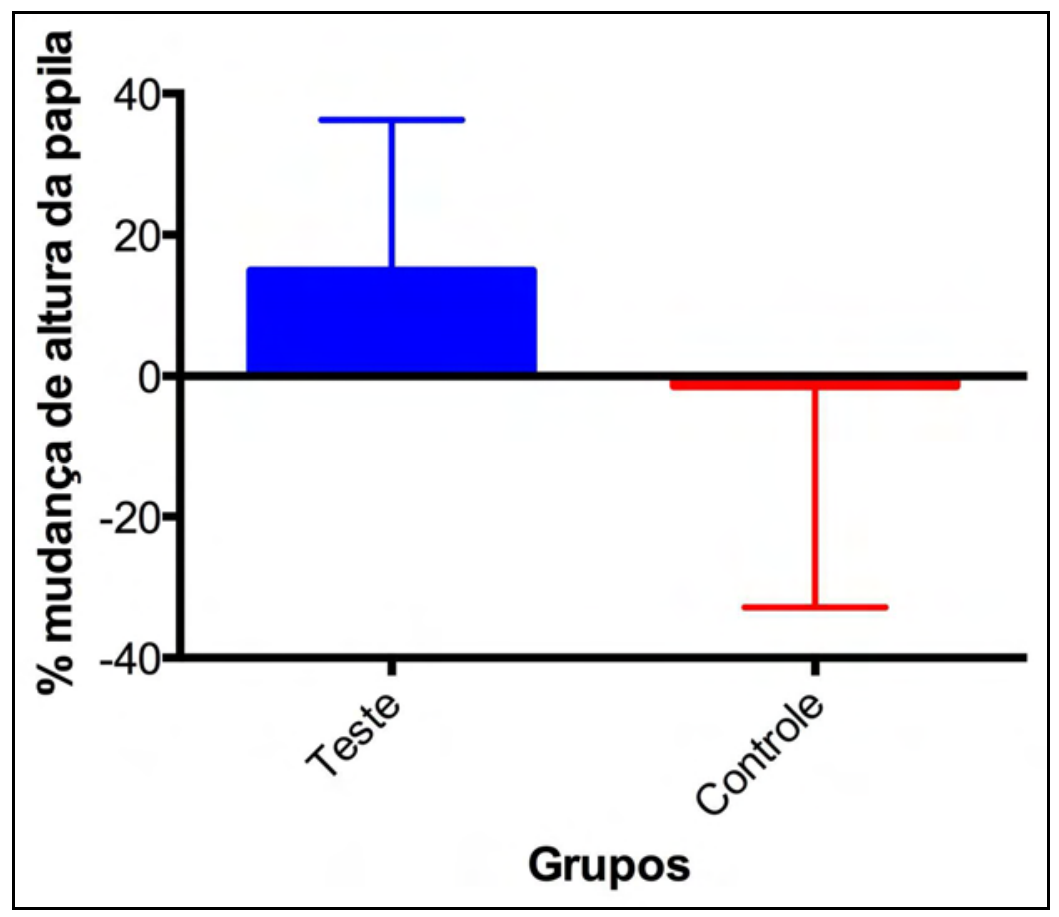

Figura 11- Percentual (média \pm desvio-padrão) de mudança na altura da papila interproximal aos 6 meses de acompanhamento comparativamente ao exame inicial (baseline) nos grupos teste e controle ( $p=0.19$; MannWhitney) 


\section{Largura da papila, distância entre a crista óssea alveolar, base do ponto de contato e ponta da papila}

Não houve variação estatisticamente significante na largura da papila antes e aos 4 meses após o tratamento nos grupos teste $(\mathrm{p}=0.09)$ e controle $(\mathrm{p}=0.16)$, assim como não houve variação significativa na distância entre a ponta da papila e a crista óssea alveolar, nos grupos teste $(\mathrm{p}=0.84)$ e controle $(\mathrm{p}=0.81)$ e na distância entre a base do ponto de contato e a crista óssea alveolar nos grupos teste $(\mathrm{p}=0.14)$ e controle $(\mathrm{p}=0.18)$, de acordo com o teste $\mathrm{t}$ pareado, conforme descrito na Tabela 3.

Tabela 3- Largura da papila, distância entre a crista óssea alveolar e base do ponto de contato e distância entre a crista óssea alveolar e a ponta da papila nos grupos teste e controle no exame inicial e aos 4 meses pósoperatório

\begin{tabular}{llcccc} 
& Grupos & Períodos & Diferença & p** \\
& & Baseline & 4 meses & \\
\hline LP & Teste & $3,59 \pm 0,80$ & $3,81 \pm 0,90$ & $0.22 \pm 0.41$ & 0.09 \\
& Controle & $2,88 \pm 0,33$ & $3,11 \pm 0,60$ & $0.22 \pm 0.44$ & 0.16 \\
& $\mathrm{p}^{*}$ & 0.02 & 0.05 & $>0.05$ & \\
\hline PP-CA & Teste & $4,84 \pm 0,58$ & $4,86 \pm 0,86$ & $0,02 \pm 0,52$ & 0.84 \\
& Controle & $4,50 \pm 0,97$ & $4,47 \pm 1,11$ & $0,02 \pm 0,59$ & 0.81 \\
& $\mathrm{p}^{*}$ & 0.17 & 0.21 & $>0.05$ & \\
\hline PC-CA & Teste & $7,15 \pm 1,06$ & $6,97 \pm 0,83$ & $-0,18 \pm 0,56$ & 0.14 \\
& Controle & $6,94 \pm 1,11$ & $7,02 \pm 1,13$ & $0,08 \pm 0,25$ & 0.18 \\
& $\mathrm{p}^{*}$ & 0.53 & 0.87 & $>0.05$ & \\
\hline
\end{tabular}

$\mathrm{p}^{*}$ - teste t paramétrico; significante se $\mathrm{p}<0.05 ; \mathrm{p}^{* *}$ - teste $\mathrm{t}$ pareado; significante se $\mathrm{p}<0.05$

LP- largura da papila (em milímetros); PP-CA- distância entre a ponta da papila e a crista óssea alveolar (em milímetros); PC-CA- distância entre a base do ponto de contato e a crista óssea alveolar (em milímetros); média \pm desvio-padrão

\section{Área de deficiência de papila}

A área de deficiência de papila (pixels $/ \mathrm{mm}^{2}$ ) reduziu no grupo teste aos 6 meses de acompanhamento $(-6,54 \% \pm 39,10 \%)$, enquanto que, no grupo controle, houve pequeno aumento da área de deficiência de papila $(5,76 \% \pm 46,34 \%)$, entretanto sem diferenças significantes entre os grupos, segundo o teste não paramétrico de Mann Whitney (Figura 12). 


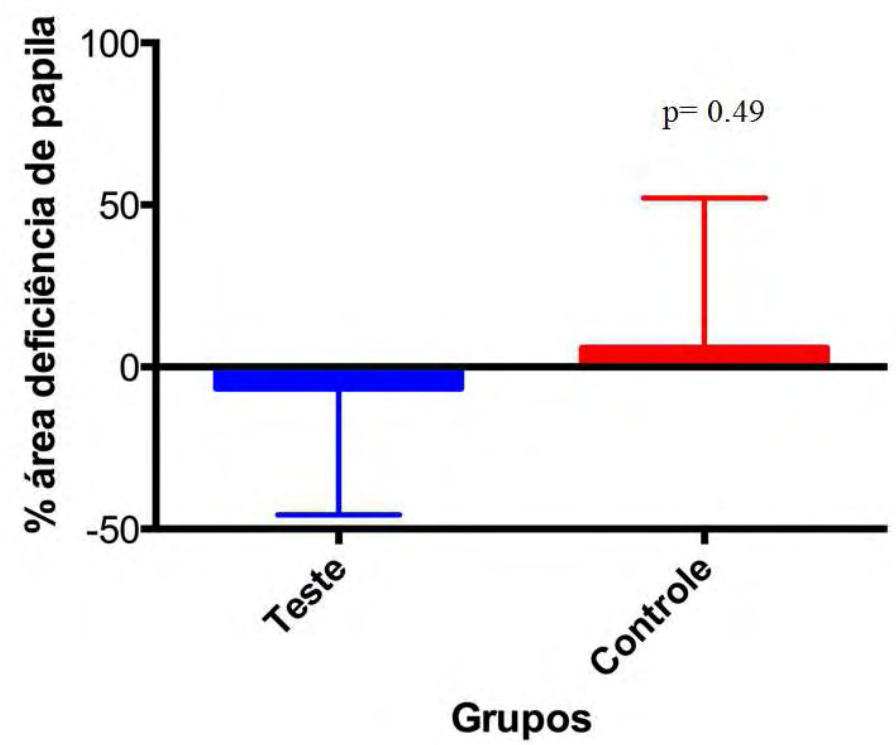

Figura 12- Percentual (média \pm desvio-padrão) da área de deficiência de papila nos grupos teste e controle aos 6 meses de acompanhamento (teste não paramétrico de Mann Whitney

\section{Distância linear ponta da papila - ponto de contato}

Similarmente, houve diminuição pequena da distância entre a ponta da papila e a base do ponto de contato observada nas imagens fotográficas (em pixels/mm) pré- e 6 meses póstratamento no grupo teste $(-2,50 \% \pm 38,60 \%)$, enquanto que, no grupo controle, observou-se pequeno aumento da distância $(10,47 \% \pm 39,37 \%)$, porém sem diferenças estatisticamente significantes entre os grupos ( $p=0.40$; Mann Whitney), conforme ilustrado na Figura 13.

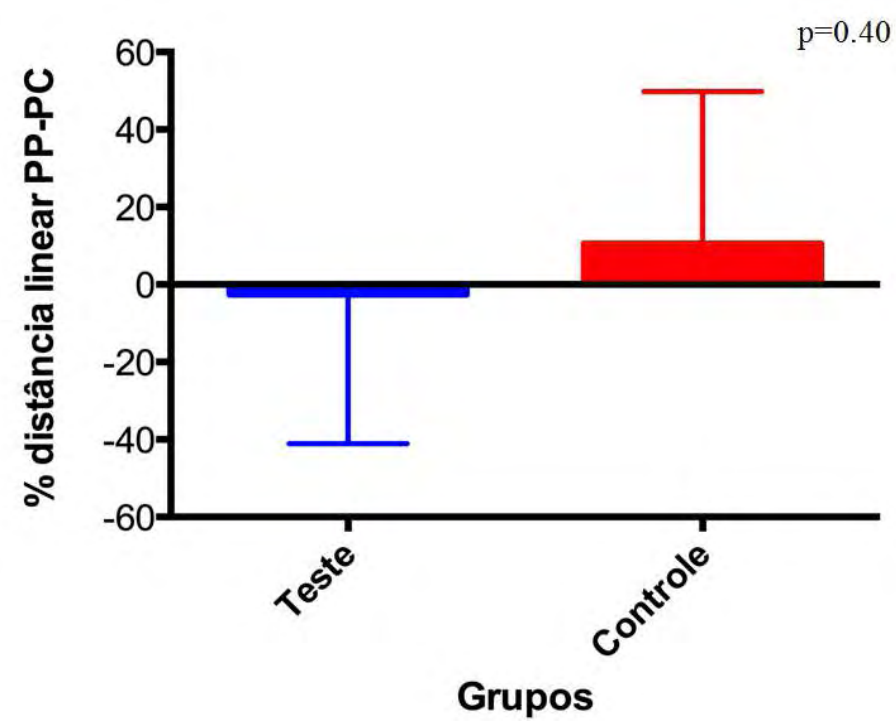

Figura 13- Percentual (média \pm desvio-padrão) da distância linear ponta da papila-base do ponto de contato nos grupos teste e controle aos 6 meses de acompanhamento (teste não paramétrico de Mann Whitney) 


\section{Índice de papila modificado (IPM)}

Três pacientes apresentaram melhora do Índice de Papila Modificado, sendo dois em sítios teste e 1 em sítio controle. Houve prevalência dos escores 1 e 2 nos grupos teste (respectivamente , 27,28\% e 72,72\%) e controle (respectivamente, 55,55\% e 44,45\%) no exame inicial. No exame final, houve maior prevalência do escore $2(72,72 \%)$ no grupo teste, onde 1 paciente apresentou papila completa (escore 3) em 1 sítio tratado no grupo teste $(9,09 \%)$, com prevalência de escore 1 em $18,18 \%$ dos sítios. No grupo controle, houve maior prevalência de escore 2 (66,67\%), enquanto que 3 sítios apresentaram escore 1 (33,33\%) no exame final, conforme descrito na Tabela 4, onde estão destacados em verde os sítios em que houve mudança no escore atribuído ao sítio de tratamento.

Tabela 4- Índice de Papila Modificado (Geurs et al. 2012) observado nos diferentes períodos de avaliação nos grupos teste e controle

\begin{tabular}{cccc|cccc}
\hline & & Teste & & \multicolumn{4}{c}{ Controle } \\
\hline Inicial & 1 & 3 & 6 & Inicial & 1 & 3 & 6 \\
$\mathbf{1}$ & 1 & 1 & 1 & 2 & 2 & 2 & 2 \\
$\mathbf{2}$ & 2 & 2 & 2 & 1 & 2 & 2 & 2 \\
$\mathbf{2}$ & 2 & 2 & $\mathbf{3}$ & 2 & 2 & 2 & 2 \\
$\mathbf{2}$ & 2 & 2 & 2 & 1 & 1 & 1 & 1 \\
$\mathbf{1}$ & 1 & 2 & 2 & 1 & 2 & 2 & $\mathbf{2}$ \\
$\mathbf{2}$ & 2 & 2 & 2 & 1 & 1 & 1 & 1 \\
$\mathbf{2}$ & 2 & 2 & 2 & 2 & 2 & 2 & 2 \\
$\mathbf{1}$ & 1 & 1 & 1 & 1 & 1 & 1 & 1 \\
$\mathbf{2}$ & 2 & 2 & 2 & 2 & 2 & 2 & 2 \\
$\mathbf{2}$ & 2 & 2 & 2 & & & & \\
$\mathbf{2}$ & 2 & 2 & 2 & & & & \\
\hline
\end{tabular}

\section{Índice de estética rosa (IER)}

Houve melhora significativa do IER observado aos 6 meses de acompanhamento em comparação com a condição inicial no grupo teste ( $\mathrm{p}=0.0078$; Wilcoxon), enquanto que não houve mudança significativa no IER observado no grupo controle aos 6 meses de acompanhamento $(\mathrm{p}=0.35)$, conforme descrito na Tabela 5 . 
Tabela 5- Análise estatística (teste de Wilcoxon) do Índice de Estética Rosa observado nos grupos teste e controle no exame inicial e aos 6 meses de acompanhamento

\begin{tabular}{llcccc}
\hline & & Mediana & $\mathbf{9 5 \%}$ CI & Média & d.p. \\
\hline Teste & Inicial & 5 & $4,26-6,45$ & 5,36 & 1,62 \\
\multirow{2}{*}{ Controle } & 6 meses & 6 & $5 ., 40-7,68$ & 6,54 & 1,69 \\
& Inicial & 5 & $3,58-6,18$ & 4,88 & 1,69 \\
& 6 meses & 5 & $4,05-6,60$ & 5,33 & 1,65 \\
\hline
\end{tabular}

\section{Influência de variáveis de risco à deficiência de papila}

A análise pelo teste de correlação de Pearson não mostrou correlação entre distância PP-PC, PP-CA ou PC-CA no exame inicial para os grupos teste e controle ( $p>0.05)$. Houve correlação entre largura da papila (LP) no exame inicial e aos 4 meses pós-operatórios no grupo teste $(r=0.891 ; p<0.0001)$. Houve correlação negativa $(r=-0.253 ; p<0.0001)$ entre PPCA no exame inicial e aos 4 meses para o grupo teste e positiva $(\mathrm{r}=0.532 ; \mathrm{p}=0.022)$ para o grupo controle. Ainda, foi observada correlação positiva entre PP-CA e PC-CA no exame inicial para o grupo controle $(r=0.642 ; p=0.004)$ e entre PP-CA aos 4 meses e PC-CA no exame inicial também para o grupo controle $(r=0.639 ; \mathrm{p}=0.019)$.

$\mathrm{Na}$ Tabela 6, estão descritas as características relacionadas à deficiência de papila e condição periodontal dos sítios incluídos nos grupos teste e controle. 
Tabela 6- Distância PC-CA, PP-PC no exame inicial e final, percentual de mudança na altura da papila e condição periodontal dos sítios/pacientes incluídos nos grupos teste e controle

\begin{tabular}{|c|c|c|c|c|c|c|c|}
\hline \# & $\begin{array}{l}\text { Classificação de } \\
\text { doença periodontal }\end{array}$ & Papila & Grupo & $\begin{array}{l}\text { PC-CA } \\
\text { (inicial) }\end{array}$ & $\begin{array}{l}\text { PP-PC } \\
\text { (inicial) }\end{array}$ & $\begin{array}{l}\text { PP-PC } \\
\text { (final) }\end{array}$ & $\%$ \\
\hline \multirow[t]{5}{*}{1} & \multirow[t]{5}{*}{ moderada } & $13 / 12$ & $\mathrm{~T}$ & 6,5 & 1,5 & 0,5 & $66,67 \%$ \\
\hline & & $12 / 11$ & $\mathrm{~T}$ & 7,0 & 3,0 & 3,0 & $0 \%$ \\
\hline & & $11 / 21$ & $\mathrm{~T}$ & 8,0 & 4,0 & 3,0 & $25 \%$ \\
\hline & & $21 / 22$ & $\mathrm{C}$ & 6,5 & 1,5 & 2,0 & $-33,34 \%$ \\
\hline & & $22 / 23$ & $\mathrm{C}$ & 9,0 & 3,0 & 2,0 & $33,34 \%$ \\
\hline \multirow[t]{5}{*}{2} & \multirow[t]{5}{*}{ severa } & $13 / 12$ & $\mathrm{~T}$ & 7,0 & 2,0 & 1,5 & $25 \%$ \\
\hline & & $12 / 11$ & $\mathrm{~T}$ & 9,0 & 3,0 & 3 & $0 \%$ \\
\hline & & $11 / 21$ & $\mathrm{~T}$ & 8,0 & 3,0 & 3 & $0 \%$ \\
\hline & & $21 / 22$ & $\mathrm{C}$ & 8,0 & 3,0 & 3 & $0 \%$ \\
\hline & & $22 / 23$ & $\mathrm{C}$ & 7,0 & 3,0 & 2,5 & $50 \%$ \\
\hline \multirow[t]{2}{*}{3} & \multirow[t]{2}{*}{ severa } & $12 / 13$ & $\mathrm{C}$ & 7,0 & 2,0 & 1,0 & $50 \%$ \\
\hline & & $22 / 23$ & $\mathrm{~T}$ & 6,5 & 1,5 & 1,0 & $33,34 \%$ \\
\hline \multirow[t]{2}{*}{4} & \multirow[t]{2}{*}{ severa } & $13 / 12$ & $\mathrm{C}$ & 7,0 & 3,0 & 3,5 & $-16,67$ \\
\hline & & $12 / 11$ & $\mathrm{~T}$ & 8,5 & 3,5 & 3,0 & $14,29 \%$ \\
\hline \multirow[t]{3}{*}{5} & \multirow[t]{3}{*}{ moderada } & $13 / 12$ & $\mathrm{C}$ & 7,0 & 2,0 & 2,0 & $0 \%$ \\
\hline & & $12 / 11$ & $\mathrm{C}$ & 6,5 & 4,0 & 4,5 & $-12,50 \%$ \\
\hline & & $21 / 22$ & $\mathrm{~T}$ & 7,0 & 2,5 & 2,5 & $0 \%$ \\
\hline \multirow[t]{3}{*}{6} & \multirow[t]{3}{*}{ moderada } & $13 / 12$ & $\mathrm{C}$ & 7,5 & 1,0 & 1,5 & $-50 \%$ \\
\hline & & $12 / 11$ & $\mathrm{~T}$ & 8,0 & 2,0 & 2,0 & $0 \%$ \\
\hline & & $11 / 21$ & $\mathrm{~T}$ & 6,0 & 1,0 & 1,0 & $0 \%$ \\
\hline
\end{tabular}

Onde \#- número do paciente; PC-CA= distância ponto de contato-crista alveolar (milímetros); PP-PC= distância ponta da papila-ponto de contato (milímetros); $\%=$ percentual de mudança na altura da papila 



\section{DISCUSSÃO}





\section{DISCUSSÃO}

Esse ensaio clínico prospectivo intervencional, modelo de boca dividida, teve por objetivo avaliar os resultados clínicos obtidos após a reconstrução estética da deficiência de papila interproximal na região anterior superior com injeção de gel de ácido hialurônico comparativamente ao enxerto de tecido conjuntivo subepitelial. Os resultados obtidos demonstraram que houve melhora significativa no aspecto estético após o tratamento por meio de injeção de ácido hialurônico. Embora o preenchimento completo da papila seja possível, os resultados demonstraram diminuição da deficiência de papila similar entre os grupos tratados por meio de injeção de acido hialurônico e enxerto de conjuntivo subepitelial.

A altura da papila foi determinada clinicamente por meio da mensuração da distância entre a ponta da papila (PP) e a base do ponto de contato (PC). Os resultados demonstraram pequena redução $(\mathrm{p}>0.05)$ na distância PP-PC nos períodos de acompanhamento de 1, 3 e 6 meses de acompanhamento nos sítios tratados por meio de injeção de AH (grupo teste), enquanto que os sítios tratados por meio de enxerto de tecido conjuntivo subepitelial (grupo controle) mostraram estabilidade nos períodos de acompanhamento de 1 e 3 meses e redução muito pequena aos 6 meses de acompanhamento $(\mathrm{p}>0.05)$. Embora o preenchimento completo da área de deficiência de papila possa ser obtido, existe grande variabilidade de resultados, com raros casos $(<20 \%)$ de preenchimento completo da papila após o tratamento (AWARTANI; TATAKIS, 2015).

A maior dificuldade notada para o tratamento da deficiência de papila com injeção de ácido hialurônico foi observada durante a aplicação do mesmo na área da papila, representada pelo tecido conjuntivo gengival que ocupa o espaço interproximal abaixo do ponto de contato, em decorrência da pequena área existente para introdução do ácido hialurônico, observandose extravasamento do material através do tecido. A maior vantagem do procedimento é a possibilidade de redução da área de deficiência de papila interproximal por meio do uso de técnica não cirúrgica, diminuindo a morbidade associada ao procedimento cirúrgico. Estudo recente reportou que o desconforto com as injeções de gel de ácido hialurônico foi a principal queixa dos pacientes, embora $2 / 3$ tivessem relatado que passariam pelo procedimento novamente (AWARTANI; TATAKIS, 2015). 
O potencial terapêutico do ácido hialurônico no tratamento de deficiência de papila foi investigado recentemente (BECKER et al., 2010; MANSOURI et al., 2013; AWARTANI; TATAKIS, 2015). Becker et al investigaram os efeitos de injeção de gel de ácido hialurônico por até 3 vezes em 14 sítios de 11 pacientes, os quais foram acompanhados por 6 a 25 meses após o tratamento. Os resultados demonstraram resolução completa dos defeitos tratados em 3 sítios (27,27\%) e melhora de 88 a 97\% em 8 sítios (72,73\%). No presente estudo, houve melhora da deficiência de papila variável entre $14,29 \%$ a $66,67 \%$ em 5 dos 11 sítios tratados no grupo teste, sendo que os 6 sítios remanescentes permaneceram inalterados. Vale ponderar que todos os pacientes tratados apresentaram periodontite moderada a avançada e a distância ponto de contato-crista óssea alveolar foi maior do que $5 \mathrm{~mm}$ em todos os sítios tratados.

Em estudo recentemente publicado (AWARTANI; TATAKIS, 2015), 17 sítios tratados em 9 mulheres por meio de injeção de ácido hialurônico apresentando altura inicial média de papila de $1.2 \pm 1.8 \mathrm{~mm}^{2}$ mostraram redução da distância entre a ponta da papilla e ponto de contato para $0.7 \pm 0.7 \mathrm{~mm}^{2}$ após 6 meses de acompanhamento ( $\left.<<0.0001\right)$. Em nosso estudo, a altura inicial da papila (distância ponta da papila-ponto de contato) foi 2 vezes maior $(2,45 \pm 0,03)$ do que nos estudos previamente mencionados (BECKER et al., 2010; AWARTANI; TATAKIS, 2015), o que dificulta a resolução completa da deficiência de papila, comprometendo a estética do sorriso. Apesar dessas dificuldades, os sítios tratados por meio de injeção de ácido hialurônico mostraram diminuição gradativa, embora não significante, da altura da papila, com altura final média de 2,13 $\pm 0,97 \mathrm{~mm}$. Houve melhora da deficiência de papila em $45,45 \%$ dos casos incluídos no grupo teste, enquanto que 54,55\% permaneceram estáveis. Esses resultados foram superiores àqueles observados com a técnica de enxerto de tecido conjuntivo subepitelial descrita por Carnio (2004), considerando-se que houve melhora da deficiência de papila em 3/9 sítios (33,33\%), estabilidade em 22,22\% e piora da deficiência de papila em $44,45 \%$, possivelmente correlacionada à contração do enxerto de tecido mole. Esses achados foram semelhantes aos resultados reportados em outro estudo recente, o qual demonstraram melhora em $47 \%$ dos sítios tratados por meio de injeção de gel de ácido hialurônico aos 6 meses de acompanhamento (MANSOURI et al., 2013).

A distância entre a crista óssea alveolar e o ponto de contato está positivamente relacionada à presença de papila interdental (GEURS et al., 2012). Tarnow et al. observaram que apenas $56 \%$ dos casos mostraram formação completa de papila adjacente a dentes naturais quando a distância entre a ponto de contato e a crista óssea alveolar fosse igual a 6 mm. Quando essa distância é de $7 \mathrm{~mm}$ ou mais, há preenchimento completo de papila em 
$27 \%$ dos casos ou menos. No presente estudo, a distância PP-CA variou de 6,0 a 9,0 mm, implicando em dificuldade de formação de papila. Apesar disso, foi possível observar melhora do aspecto clínico das áreas tratadas por meio de gel de ácido hialurônico, superior àquela observada nos sítios tratados por meio de enxerto de tecido conjuntivo subepitelial. A regeneração da papila gengival pode ser resultado de 'creeping attchment', ou seja, migração coronal da margem coronal do enxerto (MATTER; CIMASONI, 1976; BELL et al., 1978).

O tratamento por meio de injeção de ácido hialurônico proporcionou melhora significativa no índice de estética rosa, utilizado por examinador cegado e calibrado para avaliar as características estéticas do tecido gengival nos sítios tratados, enquanto que os casos tratados por meio de enxerto de tecido conjuntivo subepitelial apresentaram melhora estética não significativa $(\mathrm{p}>0.05)$. Esses achados podem estar correlacionados à preservação e até mesmo melhora das características de saúde do tecido gengival, com preservação do aspecto casca-de-laranja o qual 'desapareceu' após a realização de enxerto de conjuntivo subepitelial. Além disso, o tratamento por meio de enxerto de tecido conjuntivo resultou em alteração do contorno da margem gengival, com discrepância moderada em relação ao tecido mole dos dentes adjacentes, especialmente nos primeiros meses de acompanhamento.

Foram encontradas três dificuldades principais para a realização deste estudo: compra do produto, seleção da amostra e protocolo de aplicação do gel de ácido hialurônico. A primeira dificuldade foi na compra do produto, pois o laboratório farmacêutico responsável por sua fabricação não permite a venda a dentistas, sendo necessário que um profissional da área médica se responsabilize pela compra. Esse fato pode ser creditado à legislação vigente à época da aquisição, a qual não permitia o uso de ácido hialurônico por cirurgiões-dentistas. A segunda foi na seleção da amostra, pois os pacientes recrutados inicialmente apresentavam algum dos critérios de exclusão ou não apresentavam os critérios de inclusão e a terceira dificuldade foi na aplicação do gel de ácido hialurônico, pois devido a sua densidade, ao fracionamento dos mesmos em seringas de insulina contendo $0,2 \mathrm{ml}$ da solução e ao pequeno volume de tecido gengival na área de aplicação, a introdução do gel foi bastante difícil.

Apesar disso, a técnica parece ser bastante promissora para o tratamento da deficiência de papila, considerando-se que trata de um procedimento não cirúrgico, pouco invasivo, de execução rápida e fácil e com pequena morbidade associada. De acordo com Awartani e Tatakis (2015), embora grande parte dos pacientes tenha relatado desconforto durante a aplicação do produto, 2/3 afirmaram que passariam novamente pelo procedimento. 
Uma limitação deste e de outros estudos investigando a eficácia da injeção de gel de ácido hialurônico (BECKER et al., 2010; MANSOURI et al., 2013; AWARTANI; TATAKIS, 2015) é o pequeno número de pacientes/sítios alocados para o tratamento. Os estudos anteriores incluíram de 14 a 21 papilas interproximais no tratamento de 9 a 11 pacientes. A limitação do número de pacientes pode ser creditada a vários fatores, como: tratamento prévio da papila, uso de antibióticos, anti-inflamatórios, medicamentos com ação sobre o tecido gengival, como bloqueadores de canais de cálcio e ciclosporina, por exemplo, doenças sistêmicas mal controladas, dentre outros. Estas dificuldades também foram encontradas no presente estudo que teve como principal diferença em relação aos anteriores o modelo de boca dividida, onde o tratamento de deficiência de papila pelo uso de injeção de ácido hialurônico foi comparado com o tratamento por técnica cirúrgica convencional (enxerto de tecido conjuntivo subepitelial), considerada atualmente como padrão-ouro para reconstituição dos tecidos moles ao redor de dentes naturais e implantes (EDEL, 1995), no mesmo indivíduo, minimizando assim a possível influência da resposta biológica do paciente ao tratamento nos resultados.

Outro aspecto a ser considerado é a forma de avaliação dos resultados. No presente estudo, as variações na altura da papila ao longo do período de observação foram investigadas clinicamente e em imagens fotográficas, as quais permitem uma visão bidimensional de um objeto tridimensional e não fornecem informações precisas das mudanças de volume observadas (AWARTANI; TATAKIS, 2015). No entanto, o resultado obtido por meio da análise das imagens fotográficas reiterou os achados das avaliações clínicas, evidenciando ligeiro ganho de altura da papila nos sítios teste e leve perda de altura da papila nos sítios controle.

O ganho de papila, no presente estudo, foi gradativamente aumentando ao longo do tempo, como descrito anteriormente (MANSOURI et al., 2013). No entanto, outro estudo (AWARTANI; TATAKIS, 2015) indicou que ocorre aumento do volume da papila aos 4 meses, seguido de diminuição da altura aos 6 meses. Essas diferenças poderiam se creditadas ao material utilizado e a diferenças no tamanho dos defeitos tratados.

O gel de ácido hialurônico utilizado nesse estudo é de origem não animal, estabilizado, de alta densidade, utilizado para o preenchimento intradérmico de rugas e aumento de volume dos lábios. O uso de produto não animal minimiza a possibilidade de reações alérgicas (AWARTANI; TATAKIS, 2015) e pode ser utilizado para o preenchimento dos chamados 
"triângulos negros" resultantes da deficiência de papila, possibilitando melhora da estética sem nenhuma ou com pouca morbidade associada.

O tratamento dos "triângulos negros" pode ser subdividido em dois grupos: invasivo e não invasivo. Dentre as técnicas não invasivas estão movimento ortodôntico, redução de esmalte proximal (stripping), tratamento restaurador e instrumentação periodontal não cirúrgica (SHAPIRO, 1985; ZACHRISSON, 2004; SHARMA; PARK, 2010). A injeção local de preenchedores e outros materiais compreendem formas de tratamento não cirúrgicas ou minimamente invasivas (MCGUIRE; SCHEYER, 2007; BECKER et al., 2010). O comércio de produtos derivados de seres humanos no Brasil apresentam grandes limitações, o que não se aplica ao ácido hialurônico. As formas cirúrgicas de tratamento incluem cirurgia a retalho (BEAGLE, 1992), a qual pode ser combinada com o uso de materiais biológicos (GEURS et al., 2012), células tronco (PRATO et al., 2003; MCGUIRE; SCHEYER, 2007) ou enxertos de tecido mole (AZZI; ETIENNE; CARRANZA, 1998; NEMCOVSKY, 2001). Os procedimentos mais invasivos são acompanhados de maior morbidade, embora possibilitem a estabilidade em longo prazo (AWARTANI; TATAKIS, 2015).

Embora esse estudo tenha limitações especialmente relacionadas ao pequeno número de pacientes incluídos na amostra, os resultados obtidos são bastante promissores. É necessária a realização de ensaios clínicos randomizados, controlados, com maior número de sítios incluídos para tratamento para que se possa determinar os resultados do tratamento de deficiência de papila por meio de injeção de gel de ácido hialurônico. 



\section{CONCLUSÕes}





\section{CONCLUSÕES}

Dentro dos limites deste estudo, os resultados obtidos permitiram concluir que o tratamento da deficiência de papila por meio de injeção de gel de ácido hialurônico promove pequena melhora da deficiência de papila, similar aos resultados obtidos com o tratamento por meio de enxerto de tecido conjuntivo subepitelial, porém com melhora estética significativa relacionada especialmente às características de cor e textura do tecido relativamente aos tecidos moles adjacentes. 



\section{REFERÊNCIAS}





\section{REFERÊNCIAS}

Ainamo J, Bay I. Problems and proposals for recording gingivitis and plaque. Int Dent J. 1975 Dec;25(4):229-35.

Awartani FA, Tatakis DN. Interdental papilla loss: treatment by hyaluronic acid gel injection: a case series. Clin Oral Investig. 2015 Nov 27;

Azzi R, Etienne D, Carranza F. Surgical reconstruction of the interdental papilla. Int J Periodontics Restorative Dent. 1998 Oct;18(5):466-73.

Azzi R, Etienne D, Sauvan JL, Miller PD. Root coverage and papilla reconstruction in Class IV recession: a case report. Int J Periodontics Restorative Dent. 1999 Oct;19(5):449-55.

Azzi R, Etienne D, Takei H, Fenech P. Surgical thickening of the existing gingiva and reconstruction of interdental papillae around implant-supported restorations. Int J Periodontics Restorative Dent. 2002 Feb;22(1):71-7.

Azzi R, Takei HH, Etienne D, Carranza FA. Root coverage and papilla reconstruction using autogenous osseous and connective tissue grafts. Int J Periodontics Restorative Dent. 2001 Apr;21(2):141-7.

Beagle JR. Surgical reconstruction of the interdental papilla: case report. Int J Periodontics Restorative Dent. 1992 12(2):145-51.

Becker W, Gabitov I, Stepanov M, Kois J, Smidt A, Becker BE. Minimally invasive treatment for papillae deficiencies in the esthetic zone: a pilot study. Clin Implant Dent Relat Res. 2010 Mar;12(1):1-8.

Bell LA, Valluzzo TA, Garnick JJ, Pennel BM. The presence of "creeping attachment" in human gingiva. J Periodontol. 1978 Oct;49(10):513-7.

Bertl K, Bruckmann C, Isberg PE, Klinge B, Gotfredsen K, Stavropoulos A. Hyaluronan in non-surgical and surgical periodontal therapy: a systematic review. J Clin Periodontol. 2015 Mar;42(3):236-46.

Cardaropoli D, Re S, Corrente G, Abundo R. Reconstruction of the maxillary midline papilla following a combined orthodontic-periodontic treatment in adult periodontal patients. J Clin Periodontol. 2004 Feb;31(2):79-84.

Chen MC, Liao YF, Chan CP, Ku YC, Pan WL, Tu YK. Factors influencing the presence of interproximal dental papillae between maxillary anterior teeth. J Periodontol. 2010 Feb;81(2):318-24. 
Cho HS, Jang HS, Kim DK, Park JC, Kim HJ, Choi SH, et al. The effects of interproximal distance between roots on the existence of interdental papillae according to the distance from the contact point to the alveolar crest. J Periodontol. 2006 Oct;77(10):1651-7.

Cohen B. Morphological Factors in the pathogenesis of the periodontal disease. British Dental Journal. 1959 7(31-9).

Dahiya P, Kamal R. Hyaluronic Acid: a boon in periodontal therapy. N Am J Med Sci. 2013 May;5(5):309-15.

Dover JS CA, Carruthers J, Alam M. Clinical use of RESTYLANE. Skin Therapy Lett. 2005 $10(3)$.

Duranti F, Salti G, Bovani B, Calandra M, Rosati ML. Injectable hyaluronic acid gel for soft tissue augmentation. A clinical and histological study. Dermatol Surg. 1998 Dec;24(12):131725 .

Edel A. The use of a connective tissue graft for closure over an immediate implant covered with occlusive membrane. Clin Oral Implants Res. 1995 Mar;6(1):60-5.

Eick S, Renatus A, Heinicke M, Pfister W, Stratul SI, Jentsch H. Hyaluronic Acid as an adjunct after scaling and root planing: a prospective randomized clinical trial. J Periodontol. $2013 \mathrm{Jul} ; 84(7): 941-9$.

Elson ML. Soft tissue augmentation. A review. Dermatol Surg. 1995 Jun;21(6):491-500; quiz $1-2$.

Evian CI, Corn H, Rosenberg ES. Retained interdental papilla procedure for maintaining anterior esthetics. Compend Contin Educ Dent. 1985 Jan;6(1):58-64.

Fawzy El-Sayed KM, Dahaba MA, Aboul-Ela S, Darhous MS. Local application of hyaluronan gel in conjunction with periodontal surgery: a randomized controlled trial. Clin Oral Investig. 2012 Aug;16(4):1229-36.

Fawzy El-Sayed KM, Mekhemar MK, Beck-Broichsitter BE, Bahr T, Hegab M, Receveur J, et al. Periodontal regeneration employing gingival margin-derived stem/progenitor cells in conjunction with IL-1 ra-hydrogel synthetic extracellular matrix. J Clin Periodontol. 2015 May;42(5):448-57.

Furhauser R, Florescu D, Benesch T, Haas R, Mailath G, Watzek G. Evaluation of soft tissue around single-tooth implant crowns: the pink esthetic score. Clin Oral Implants Res. 2005 Dec;16(6):639-44.

Gargiulo AW, Wentz, F.M., Orban, B. Dimensions and relations of the dentogingival junction in humans. . Journal of Periodontology. 1961 32(3):261-7.

Gastaldo JF, Cury PR, Sendyk WR. Effect of the vertical and horizontal distances between adjacent implants and between a tooth and an implant on the incidence of interproximal papilla. J Periodontol. 2004 Sep;75(9):1242-6. 
Geurs NC, Romanos AH, Vassilopoulos PJ, Reddy MS. Efficacy of micronized acellular dermal graft for use in interproximal papillae regeneration. Int J Periodontics Restorative Dent. 2012 Feb;32(1):49-58.

Goa KL, Benfield P. Hyaluronic acid. A review of its pharmacology and use as a surgical aid in ophthalmology, and its therapeutic potential in joint disease and wound healing. Drugs. 1994 Mar;47(3):536-66.

Gonzalez MK, Almeida AL, Greghi SL, Pegoraro LF, Mondelli J, Moreno T. Interdental papillary house: a new concept and guide for clinicians. Int J Periodontics Restorative Dent. 2011 Nov-Dec;31(6):e87-93.

Göttfert F, Striegel M. Hyaluronic acid at its best. 2015 [28/11/2015]. Available from: http://puredent.dk/hyaluronic-acid-at-its-best/.

Han TJ, Takei HH. Progress in gingival papilla reconstruction. Periodontol 2000. 1996 Jun;11(65-8).

Ingber JS. Forced eruption: alteration of soft tissue cosmetic deformities. Int J Periodontics Restorative Dent. 1989 9(6):416-25.

Jordan DR. Soft-tissue fillers for wrinkles, folds and volume augmentation. Can J

Ophthalmol. 2003 Jun;38(4):285-8.

Kolte AP, Kolte RA, Mishra PR. Dimensional influence of interproximal areas on existence of interdental papillae. J Periodontol. 2014 Jun;85(6):795-801.

Lupton JR, Alster TS. Cutaneous hypersensitivity reaction to injectable hyaluronic acid gel. Dermatol Surg. 2000 Feb;26(2):135-7.

Mansouri SS, Ghasemi M, Salmani Z, Shams N. Clinical Application of Hyaluronic Acid Gel for Reconstruction of Interdental Papilla at the Esthetic zone. Journal of Islamic Dental Association of IRAN (JIDAI) 2013 25(2):6.

Martegani P, Silvestri M, Mascarello F, Scipioni T, Ghezzi C, Rota C, et al. Morphometric study of the interproximal unit in the esthetic region to correlate anatomic variables affecting the aspect of soft tissue embrasure space. J Periodontol. 2007 Dec;78(12):2260-5.

Matarasso SL, Carruthers JD, Jewell ML, Group. RC. Consensus Recommendations for SoftTissue Augmentation with Nonanimal Stabilized Hyaluronic Acid (Restylane). Plast Reconstr Surg. 2006 117((3 Suppl)):32.

Matarasso SL, Herwick R. Hypersensitivity reaction to nonanimal stabilized hyaluronic acid. J Am Acad Dermatol. 2006 55(1):4.

Matter J, Cimasoni G. Creeping attachment after free gingival grafts. J Periodontol. 1976 Oct;47(10):574-9. 
McGuire MK, Scheyer ET. A randomized, double-blind, placebo-controlled study to determine the safety and efficacy of cultured and expanded autologous fibroblast injections for the treatment of interdental papillary insufficiency associated with the papilla priming procedure. J Periodontol. 2007 Jan;78(1):4-17.

Nemcovsky CE. Interproximal papilla augmentation procedure: a novel surgical approach and clinical evaluation of 10 consecutive procedures. Int J Periodontics Restorative Dent. 2001 Dec;21(6):553-9.

Nordland WP, Sandhu HS, Perio C. Microsurgical technique for augmentation of the interdental papilla: three case reports. Int J Periodontics Restorative Dent. 2008

Dec;28(6):543-9.

Nordland WP, Tarnow DP. A classification system for loss of papillary height. J Periodontol. 1998 Oct;69(10):1124-6.

O'Leary TJ, Drake RB, Naylor JE. The plaque control record. J Periodontol. 1972 Jan;43(1):38.

Ochsenbein C. Osseous Resection in Periodontal Surgery. Journal of Periodontology 1958 29(1):15-26

Perez F, Martins Segalla JC, Ferreira PM, Pereira Lauris JR, Rabelo Ribeiro JG. Clinical and radiographic evaluation of factors influencing the presence or absence of interproximal gingival papillae. Int J Periodontics Restorative Dent. 2012 Apr;32(2):e68-74.

Pinheiro MV, Bagatin E, Hassun KM, Talarico S. Adverse effect of soft tissue augmentation with hyaluronic acid. J Cosmet Dermatol. 2005 4(3):3.

Pini Prato GP, Rotundo R, Magnani C, Soranzo C. Tissue engineering technology for gingival augmentation procedures: a case report. Int J Periodontics Restorative Dent. 2000 Dec;20(6):552-9.

Pirnazar P, Wolinsky L, Nachnani S, Haake S, Pilloni A, Bernard GW. Bacteriostatic effects of hyaluronic acid. J Periodontol. 1999 Apr;70(4):370-4.

Prato GP, Rotundo R, Cortellini P, Tinti C, Azzi R. Interdental papilla management: a review and classification of the therapeutic approaches. Int J Periodontics Restorative Dent. 2004 Jun;24(3):246-55.

Prato GP, Rotundo R, Magnani C, Soranzo C, Muzzi L, Cairo F. An autologous cell hyaluronic acid graft technique for gingival augmentation: a case series. J Periodontol. 2003 Feb;74(2):262-7.

Price RB, Price DE. Esthetic restoration of a single-tooth dental implant using a subepithelial connective tissue graft: a case report with 3-year follow-up. Int J Periodontics Restorative Dent. 1999 Feb;19(1):92-101. 
Rohrich RJ, Ghavami A, Crosby MA. The role of hyaluronic acid fillers (Restylane) in facial cosmetic surgery: review and technical considerations. Plast Reconstr Surg. 2007 Nov;120(6 Suppl):41S-54S.

Salama H, Salama MA, Garber D, Adar P. The interproximal height of bone: a guidepost to predictable aesthetic strategies and soft tissue contours in anterior tooth replacement. Pract Periodontics Aesthet Dent. 1998 Nov-Dec;10(9):1131-41; quiz 42.

Sawai M, Kohad R. An evaluation of a periodontal plastic surgical procedure for the reconstruction of interdental papillae in maxillary anterior region: A clinical study. J Indian Soc Periodontol 2012 Oct;16(4):533-8.

Saxena D, Kapoor A, Malhotra R, Grover V. Embrasure morphology and central papilla recession. J Indian Soc Periodontol. 2014 Mar;18(2):194-9.

Shapiro A. Regeneration of interdental papillae using periodic curettage. Int J Periodontics Restorative Dent. 1985 5(5):26-33.

Sharma AA, Park JH. Esthetic considerations in interdental papilla: remediation and regeneration. J Esthet Restor Dent. 2010 Feb;22(1):18-28.

Tal H. Relationship between the interproximal distance of roots and the prevalence of intrabony pockets. J Periodontol. 1984 Oct;55(10):604-7.

Tarnow DP, Magner AW, Fletcher P. The effect of the distance from the contact point to the crest of bone on the presence or absence of the interproximal dental papilla. J Periodontol. 1992 Dec;63(12):995-6.

Tinti C, Benfenati SP. The ramp mattress suture: a new suturing technique combined with a surgical procedure to obtain papillae between implants in the buccal area. Int J Periodontics Restorative Dent. 2002 Feb;22(1):63-9.

Wu YJ, Tu YK, Huang SM, Chan CP. The influence of the distance from the contact point to the crest of bone on the presence of the interproximal dental papilla. Chang Gung Med J. 2003 Nov;26(11):822-8.

Zachrisson BU. Interdental papilla reconstruction in adult orthodontics. World J Orthod. 2004 Spring;5(1):67-73.

Zetu L, Wang HL. Management of inter-dental/inter-implant papilla. J Clin Periodontol. 2005 Jul;32(7):831-9. 

Anexos 

ANEXO I - Parâmetros periodontais dos sítios de tratamento nos grupos teste e controle no exame inicial

\begin{tabular}{|c|c|c|c|c|c|c|c|c|c|c|c|c|c|c|c|c|c|c|c|c|c|c|c|c|}
\hline \multirow[t]{2}{*}{ Paciente } & \multirow[t]{2}{*}{ Sítio } & \multirow[t]{2}{*}{ Grupo } & \multicolumn{6}{|l|}{ PS } & \multicolumn{5}{|l|}{ NIC } & \multicolumn{6}{|l|}{ ISS } & \multicolumn{5}{|l|}{ IPI } \\
\hline & & & MV & $\mathrm{V}$ & DV & ML & $\mathrm{L}$ & $\overline{\mathrm{DL}}$ & MV & $\mathrm{V}$ & DV & ML & $\mathrm{L}$ & $\mathrm{DL}$ & MV & $\bar{V}$ & DV & ML & $\mathrm{L}$ & $\mathrm{DL}$ & $\bar{M}$ & $\mathrm{~V}$ & $\mathrm{D}$ & $\mathrm{L}$ \\
\hline \multirow[t]{6}{*}{1} & 13 & $\mathrm{~T}$ & 2 & 2 & 2 & 2 & 3 & 3 & 4 & 5 & 4 & 0 & 1 & 1 & 0 & 0 & 0 & 0 & 0 & 0 & 0 & 0 & 0 & 0 \\
\hline & 12 & $\mathrm{~T}$ & 2 & 2 & 2 & 3 & 3 & 1 & 0 & 3 & 0 & 1 & 1 & 0 & 0 & 0 & 0 & 0 & 0 & 0 & 0 & 0 & 0 & 0 \\
\hline & 11 & $\mathrm{~T}$ & 2 & 2 & 2 & 2 & 2 & 2 & 0 & 0 & 0 & 0 & 0 & 0 & 0 & 0 & 0 & 0 & 0 & 0 & 0 & 0 & 0 & 0 \\
\hline & 21 & $\mathrm{~T} / \mathrm{C}$ & 2 & 2 & 2 & 2 & 2 & 2 & 4 & 4 & 4 & 0 & 0 & 0 & 0 & 0 & 0 & 0 & 0 & 0 & 0 & 0 & 0 & 0 \\
\hline & 22 & $\mathrm{C}$ & 2 & 2 & 2 & 2 & 2 & 2 & 4 & 5 & 4 & 0 & 0 & 0 & 0 & 0 & 0 & 0 & 0 & 0 & 0 & 0 & 0 & 0 \\
\hline & 23 & $\mathrm{C}$ & 2 & 3 & 2 & 2 & 2 & 1 & 3 & 4 & 3 & 0 & 0 & 0 & 0 & 0 & 0 & 0 & 0 & 0 & 0 & 0 & 0 & 0 \\
\hline \multirow[t]{6}{*}{2} & 13 & $\mathrm{~T}$ & 1 & 2 & 2 & 4 & 3 & 4 & 3 & 6 & 4 & 2 & 2 & 0 & 0 & 0 & 0 & 0 & 0 & 0 & 0 & 0 & 0 & 0 \\
\hline & 12 & $\mathrm{~T}$ & 2 & 2 & 2 & 4 & 3 & 1 & 3 & 4 & 2 & 2 & 0 & 0 & 0 & 0 & 0 & 0 & 0 & 0 & 0 & 0 & 0 & 0 \\
\hline & 11 & $\mathrm{~T} / \mathrm{C}$ & 2 & 2 & 2 & 2 & 2 & 2 & 0 & 0 & 0 & 0 & 0 & 0 & 0 & 0 & 0 & 0 & 0 & 0 & 0 & 0 & 0 & 0 \\
\hline & 21 & $\mathrm{C} / \mathrm{T}$ & 2 & 2 & 2 & 1 & 1 & 1 & 3 & 4 & 0 & 0 & 0 & 0 & 0 & 0 & 0 & 0 & 0 & 0 & 0 & 0 & 0 & 0 \\
\hline & 22 & $\mathrm{C}$ & 2 & 2 & 2 & 2 & 2 & 2 & 3 & 4 & 0 & 0 & 0 & 0 & 0 & 0 & 0 & 0 & 0 & 0 & 0 & 0 & 0 & 0 \\
\hline & 23 & $\mathrm{C}$ & 2 & 3 & 2 & 2 & 2 & 1 & 4 & 6 & 0 & 0 & 0 & 0 & 0 & 0 & 0 & 0 & 0 & 0 & 0 & 0 & 0 & 0 \\
\hline \multirow[t]{4}{*}{3} & 12 & $\mathrm{C}$ & 3 & 2 & 2 & 4 & 2 & 2 & 1 & 0 & 0 & 2 & 0 & 0 & 0 & 0 & 1 & 1 & 1 & 0 & 0 & 0 & 0 & 0 \\
\hline & 11 & $\mathrm{C}$ & 2 & 3 & 3 & 4 & 2 & 3 & 5 & 5 & 4 & 5 & 0 & 1 & 0 & 0 & 1 & 1 & 1 & 0 & 0 & 0 & 0 & 0 \\
\hline & 21 & $\mathrm{~T}$ & 2 & 3 & 2 & 2 & 1 & 1 & 4 & 3 & 3 & 3 & 0 & 0 & 0 & 0 & 0 & 0 & 0 & 0 & 0 & 0 & 0 & 0 \\
\hline & 22 & $\mathrm{~T}$ & 2 & 2 & 2 & 1 & 2 & 2 & 0 & 2 & 0 & 0 & 0 & 0 & 0 & 0 & 0 & 1 & 0 & 0 & 0 & 0 & 0 & 0 \\
\hline \multirow[t]{3}{*}{4} & 13 & C & 2 & 1 & 5 & 2 & 1 & 2 & 4 & 4 & 7 & 3 & 4 & 4 & 0 & 1 & 1 & 1 & 1 & 1 & 1 & 0 & 1 & 0 \\
\hline & 12 & $\mathrm{~T}$ & 2 & 1 & 3 & 2 & 1 & 2 & 3 & 0 & 1 & 0 & 2 & 0 & 0 & 1 & 0 & 0 & 1 & 1 & 1 & 1 & 1 & 0 \\
\hline & 11 & $\mathrm{~T}$ & 1 & 1 & 3 & 2 & 1 & 2 & 0 & 0 & 3 & 0 & 0 & 0 & 1 & 1 & 1 & 0 & 1 & 1 & 0 & 0 & 1 & 0 \\
\hline
\end{tabular}


...continuação

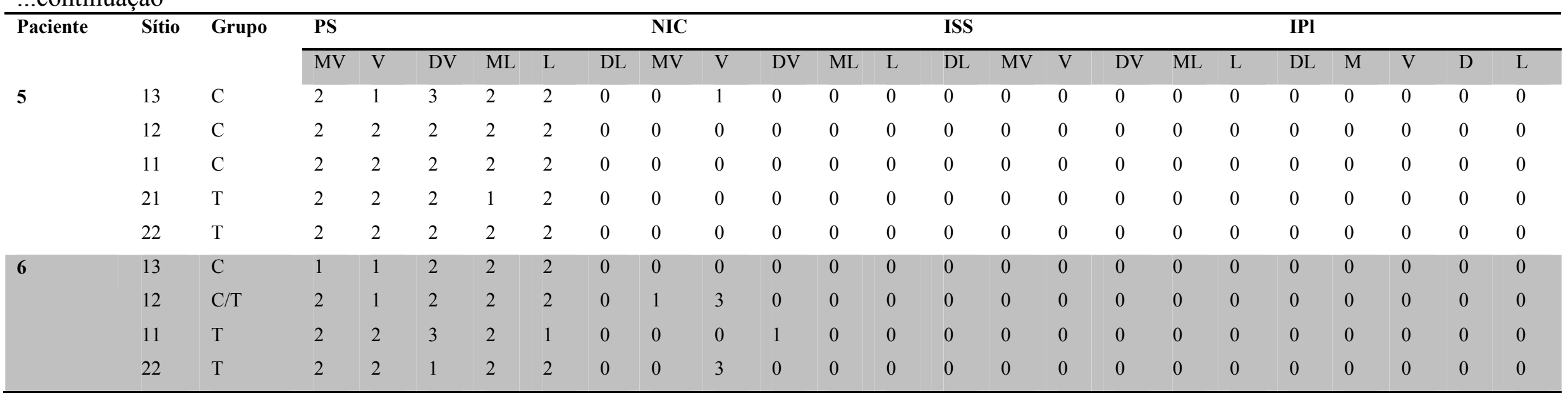

